\title{
Symptoms of Autism Spectrum Disorder and Developmental Delay in Children with Low Mental Age
}

\author{
Rebecca P. Thomas \\ University of Connecticut - Storrs, rebecca.p.thomas@uconn.edu
}

Follow this and additional works at: https://opencommons.uconn.edu/gs_theses

\section{Recommended Citation}

Thomas, Rebecca P., "Symptoms of Autism Spectrum Disorder and Developmental Delay in Children with Low Mental Age" (2020). Master's Theses. 1517.

https://opencommons.uconn.edu/gs_theses/1517

This work is brought to you for free and open access by the University of Connecticut Graduate School at OpenCommons@UConn. It has been accepted for inclusion in Master's Theses by an authorized administrator of OpenCommons@UConn. For more information, please contact opencommons@uconn.edu. 
Symptoms of Autism Spectrum Disorder and Developmental Delay in Children with Low Mental Age

\author{
Rebecca Podell Thomas \\ B.A., Bowdoin College, 2010 \\ M.A., Teachers College Columbia University, 2014
}

\author{
A Thesis \\ Submitted in Partial Fulfillment of the \\ Requirements for the Degree of \\ Master of Science \\ at the \\ University of Connecticut
}

2020 
Copyright by

Rebecca Podell Thomas

2020 


\title{
APPROVAL PAGE
}

\section{Master of Science Thesis}

Symptoms of Autism Spectrum Disorder and Developmental Delay in Children with Low

\author{
Mental Age
}

Presented by Rebecca Podell Thomas, B.A., MA.

Major Advisor:

Deborah A. Fein, Ph.D.

Associate Advisor:

Stephanie Milan, Ph.D.

Associate Advisor:

Letitia Naigles, Ph.D.

University of Connecticut 


\title{
ACKNOWLEDGEMENTS
}

\author{
Committee \\ Deborah Fein, Ph.D., Stephanie Milan, Ph.D., Letitia Naigles, Ph.D.
}

Early Detection Team

Participating Families and Children

Funding Support

Eunice Kennedy Shriver National Institute of Child Health and Human Development, R01 HD039961-05 
Table of Contents

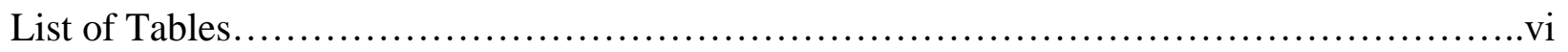

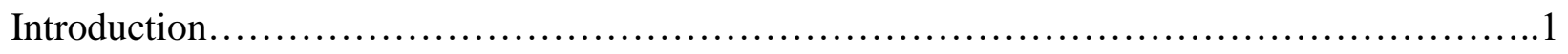

Methods.........................................................................6

Participants and Procedure...................................................

Overall Cognitive Level.............................................9

Measures...............................................................9

Mullen Scales of Early Learning .......................................

Autism Diagnostic Observation Schedule - 2nd Edition.....................10

Modified Checklist for Autism in Toddlers - Revised with Follow-up............11

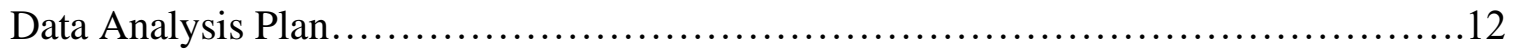

Results..................................................................... 13

Autism vs. Non-autism Comparison (ASD-low MA versus GDD) $\ldots \ldots \ldots \ldots \ldots \ldots \ldots \ldots$

M-CHAT-R/F Comparison.......................................... 13

ADOS-2 Toddler Module Comparison...................................... 14

ASD Comparison by Developmental Level (ASD-low MA versus ASD-higher MA)....15

M-CHAT-R/F Comparison.......................................... 15

ADOS-2 Toddler Module Comparison...................................... 16

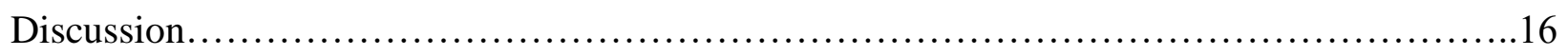


List of Tables

Table 1. Participant Characteristics by Diagnostic Group ..................................24

Table 2. Number of Children by Group who Failed M-CHAT-R/F Items (GDD versus ASD-low

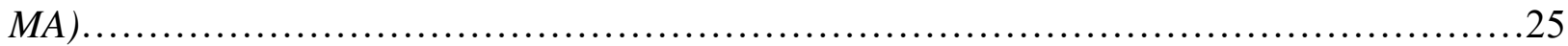

Table 3. Number of Children by Group with Endorsed ADOS-2 Toddler Module Items (GDD

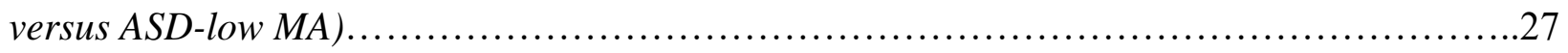

Table 4. Number of Children by Group who Failed M-CHAT-R/F Items (ASD higher-MA versus

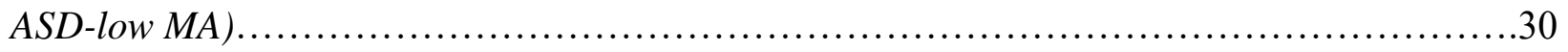

Table 5. Number of Children by Group with Endorsed ADOS-2 Toddler Module Items (ASD-

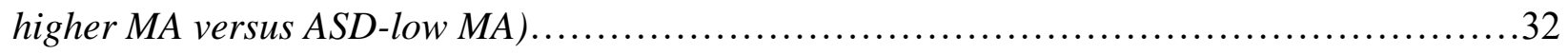




\section{Symptoms of Autism Spectrum Disorder and Developmental Delay in Children with Low}

\section{Mental Age}

Autism spectrum disorder (ASD) is a neurodevelopmental disorder classified by impairments in social communication and interaction, and the presence of restricted or repetitive patterns of behavior and interests (DSM-5; American Psychiatric Association, 2013). The American Academy of Pediatrics recommends screening for ASD in all children at 18- and 24month well child visits (Johnson \& Myers, 2007). The Modified Checklist for Autism in Toddlers (M-CHAT; Robins, Fein, Barton, \& Green, 2001) is one of the most widely used ASD screening instruments. Children who fail more than three items on the revised version of the MCHAT (M-CHAT-R/F) have a $47.5 \%$ risk of being diagnosed with ASD and a $94.6 \%$ risk of being diagnosed with some neurodevelopmental disorder (Robins et al., 2014).

Intellectual disabilities co-occur in approximately $1 / 3$ of people with an ASD diagnosis; however, intellectual disabilities are not formally diagnosed until a child is able to complete a standard IQ test, typically around six years old (Baio et al., 2018). Before that time, children can be diagnosed with general or global developmental delay (GDD), which carries less of an implication of a permanent condition. Recent analyses of national medical records found that $95 \%$ of eight-year old children with a diagnosis of ASD and a co-occurring intellectual disability had documentation of developmental concerns when they were younger than 36 months old (Baio et al., 2018). It has been suggested that very early, significant developmental delays have a high probability of leading to a diagnosed intellectual disability (Moeschler \& Shevell, 2014).

However, the co-occurrence of ASD symptoms and significant global delay in toddlers has not been studied as thoroughly. One reasonable hypothesis might be that children with very low mental ages only meet criteria for ASD because they are not developmentally at the point 
where some of the social communication skills are apparent in typical development; some proportion of these very delayed children, therefore, may meet criteria for an intellectual disability, but not ASD, at a later time.

Numerous studies have addressed the issue of diagnostic stability in ASD by examining the age at which children can be reliably diagnosed with ASD, and especially whether this diagnosis remains stable over time (Kim et al., 2018). There is also the question of whether this stability only applies to a particular subset of ASD, such as high-risk infant siblings (e.g. Ozonoff et al., 2016). There has been a fairly large literature on the early development of ASD and the age at which a diagnosis is reliable (e.g., Dawson et al., 2004; Nadig et al., 2007; Ozonoff et al., 2010, 2015; Zwaigenbaum et al., 2015, 2016). Early social and communication behaviors at 12 months can discriminate groups of children with ASD from groups with GDD and from groups of children who are typically developing (Ozonoff et al., 2010; Ozonoff \& Iosif, 2019; for review, see Mitchell et al., 2011). These early, identifiable symptoms of ASD include reduced response to name, frequency and quality of facial expressions, and the use of eye contact to coordinate social interactions (e.g., Adamson et al., 2019; Nevill et al., 2017; Osterling et al., 2002). Children with ASD also show a decline in social engagement and visual attention to social stimuli between six and 12 months (Klin et al., 2015; Ozonoff \& Iosif, 2019; Salley et al., 2016). By 18 months, children with ASD show less frequent and varied communicative gestures compared to same-age children with GDD; by two years, children with ASD also show diminished responsiveness to others, including peers, and less sharing of interests and enjoyment (Mitchell et al., 2011). Toddlers with ASD also show a unique cognitive profile, with generally lower receptive language skills compared to nonverbal skills (Barbaro \& Dissanayake, 2012; Weismer et al., 2010). Individual children can be reliably diagnosed with ASD when they are as 
young as 14 months old (Pierce et al., 2019), and changes to diagnosis generally occur with more children moving off the spectrum at later time points than onto the spectrum (Woolfenden et al., 2012). When studying the development of groups of children, groups with ASD can be differentiated from other groups by 12 months (Klin et al., 2015; Ozonoff et al., 2010).

This large literature on the early signs of ASD, however, has not yet shown a clear picture of how a severe developmental delay impacts the presentation of ASD symptoms at this very young age. Existing research suggests that the presence of cognitive impairment in young children can cloud diagnostic clarity in distinguishing ASD from other neurodevelopmental disorders, such as GDD (Gardner et al., 2018; Thurm et al., 2019).

One way to address this question is to identify whether an ASD diagnosis is stable in children who have severe developmental delays in early childhood. Hinnebusch et al. (2017) identified a group of such children, who were called "ASD-low mental age" (ASD-low MA). These children, aged 15 to 31 months, met criteria for ASD but all had cognitive skills below the 12-month level. It was hypothesized that the ASD signs in some of these children were due to their developmental delays, and therefore when seen two years later, at least some would meet criteria for GDD but not for ASD. Patterns of mental growth and rates of progress in children with ASD-low MA were compared to children with Autistic Disorder (AD) or Pervasive Developmental Disorder - Not Otherwise Specified (PDD-NOS) who had some cognitive abilities above the 12-month level. Mental growth was defined as the difference between the age equivalents at two time points; rate of progress was defined as the mental growth divided by the time elapsed between the two time points (change in mental age divided by change in chronological age). Their findings suggested that the ASD-low MA group showed the least amount of absolute growth (as measured by raw score or age equivalent) and the slowest rate of 
progress (MA/CA) on all indices of cognitive development, and almost no growth in social skills. While rates of progress did not differ between the PDD-NOS and the AD groups, the ASD-low MA group showed the slowest rate of progress, ranging from one half to one quarter of the progress expected for their chronological age and even less on social skills. These significantly slower rates of progress for the ASD-low MA group were evident on all scales of the Mullen Scales of Early Learning (MSEL; Mullen, 1995), including expressive and receptive language, visual reception, and fine motor skills. The ASD-low MA group also demonstrated almost no progress on parent reported interpersonal relationships, play and leisure, and coping subscales on the Vineland Adaptive Behavior Scales, $2^{\text {nd }}$ Edition (VABS-II; Sparrow et al., 2005). Contrary to previous research concluding that caution be used in diagnosing ASD in children with a mental age under 12 months (Esler et al., 2015; Luyster et al., 2009), and contrary to the hypothesized change in diagnosis to GDD, all but one child in the ASD-low MA group (96\%) maintained their ASD diagnosis at the second timepoint, compared to lower rates of diagnostic stability in the AD and PDD-NOS groups (Hinnebusch et al., 2017). These findings support the conclusion that the diagnosis of ASD in ASD-low MA children remains stable over time.

A recent study examined autism-specific symptomatology in a group of children with global developmental delay (GDD) compared to ASD groups with and without low mental age (Miller et al., 2019). Participants with a GDD diagnosis showed less ASD symptomatology than either ASD group on all diagnostic items on Module One of the Autism Diagnostic Observation Schedule (ADOS; Lord et al., 2000). The GDD group showed some impairments in pointing (A7) and imaginative/creative play (C2) items, but otherwise had fairly typical scores $(<1)$ on items included in the scoring algorithm for an ASD diagnosis. Since the GDD group 
demonstrated more typical social interactions, autism-specific screening and diagnostic items should theoretically not capture this group. This raises the question of whether ASD groups that vary by mental age show similar patterns of behavior to one another that distinguish them from GDD, or whether low MA in children with ASD will make it more difficult to identify ASD symptoms. Miller et al. (2019) found that the ASD-low MA group showed more severe impairments than the ASD-higher MA group on all measures. However, the ASD groups did not differ significantly on eye contact, responsive social smiling, response to name, facial expressions directed to others, and spontaneous showing. This suggests that core symptoms of ASD, as manifest to a clinician on the ADOS Module One, remain apparent even when cooccurring with a low mental age.

Research on diagnosing ASD in children with a low mental age found that the ADOS overclassified a large minority of the children with a low mental age as having ASD when their clinical diagnosis was GDD (Miller et al., 2019). One potential reason for the over-classification of this group is that this research used a prior version of the ADOS. This earlier version used a scoring algorithm that more heavily weighs social communication skills that may not be apparent in children with mental ages under 12 months (Guthrie et al., 2013). As mentioned above, the validity of an ASD diagnosis in very young children (12 months and under) has been questioned in part because 12-month old children may not be at a stage of development where typical versus atypical patterns of social communication skills are apparent; it can be difficult to separate general developmental delay from early symptoms of ASD in these very young and delayed children (Osterling et al., 2002). The current project attempts to fill this gap by using diagnostic information generated from the Toddler Module of the ADOS-2 (Lord, Luyster, Gotham, \& Guthrie, 2012). One goal of this project is to determine whether this Toddler Module is better 
able to accurately distinguish children with ASD-low MA from children with GDD, and whether symptoms of ASD are endorsed at similar rates in toddlers with ASD regardless of their mental age.

Since the ASD-low MA symptom profile is a distinct phenotype, children in this group should perform differently from GDD groups on screening and diagnostic instruments (Hinnebusch et al., 2017; Miller et al., 2019). Core features of ASD should distinguish children with ASD from children with other developmental delays. However, research suggests that existing screening measures, such as the M-CHAT-R/F (Robins et al., 2014), have higher Positive Predictive Values (PPV) in capturing children at risk of any developmental delay than ASD specifically. Since ASD is a subcategory of developmental delay or disorder, this must be true; however, there is a large discrepancy, with PPV for ASD in the moderate range ( 0.50 to 0.70), while PPV for any developmental delay or disorder is very high (0.94; Robins et al., 2014).

Identification of specific behaviors that lead to true or false positives for ASD in very delayed children may help clinicians better estimate a child's risk for ASD. This project aims to separate behaviors in the ASD-low MA group that reflect a low mental age compared to those that reflect ASD. In order to identify behaviors reflective of low MA, we will look for commonalities between children with ASD-low MA and children with GDD, and in order to identify behaviors reflective of ASD regardless of MA, we will look for commonalities between children with ASD-low MA and a group of children with ASD and a higher MA.

\section{Methods}

\section{Participants and Procedure}


Children $(N=90)$ between 12 months and 34 months of age participated in a multi-site study of early detection in ASD. The study recruited all children who screened positive on the M-CHAT-R/F or who were flagged by pediatrician concern. Children were excluded from participation in the larger study if they had significant motor or sensory impairments, such as cerebral palsy or blindness, that would interfere with the validity of testing procedures. All participants received developmental testing [Mullen Scales of Early Learning, MSEL (Mullen, 1995)] conducted by a graduate student clinician and a licensed clinical psychologist or developmental behavioral pediatrician. Participants also completed a gold-standard measure of observed autism symptomatology to establish whether the child met criteria for an autism spectrum disorder (ADOS-2; Lord et al., 2012). Parent report was obtained through the Vineland Adaptive Behavior Scales: Second Edition (Sparrow et al., 2005) and the Toddler Autism Symptom Inventory (TASI; Coulter et al., 2019) to corroborate behavioral observations of ASD symptoms and early development. Diagnoses were based on criteria from the Diagnostic and Statistical Manual of Mental Disorders, Fifth Edition (DSM-5; American Psychiatric Association, 2013) and the International Classification of Diseases, 10th edition (ICD-10; World Health Organization, 1992); participants had to meet diagnostic criteria for ASD in one or both of the classification systems through a combination of clinical observations, parent report, and ADOS-2 scores.

The ASD-low MA group ( $n=30$ ) had age equivalents $<12$ months on MSEL Expressive Language, Receptive Language, and Visual Reception subtests, and met DSM-5 diagnostic criteria for Autism Spectrum Disorder. Criteria for the ASD-low MA group are taken from Hinnebusch et al. (2017) and Miller et al., (2019). 
The Global Developmental Delay (GDD) group $(n=30)$ consisted of children who met DSM-5 criteria for Global Developmental Delay but not for ASD. The GDD criteria were operationalized as scores at least 1.5 standard deviations below the mean on at least one verbal and one non-verbal measure, at least one of which must be evident on the direct testing of the MSEL to avoid complete reliance on parent report. Verbal scores that met this criterion were MSEL Expressive or Receptive Language t-scores less than or equal to 35, or a VABS-II Communication standard score of less than or equal to 77 . Non-verbal scores that met this criterion for GDD were MSEL Visual Reception or Fine Motor t-scores less than or equal to 35, or a VABS-II Motor Skills standard score of less than or equal to 77.

The ASD-higher mental age (ASD-higher MA) group $(n=30)$ met diagnostic criteria for ASD and did not meet the low mental age criteria.

Participant characteristics by diagnostic group comparison are listed in Table 1. All children with a GDD diagnosis or an ASD-low MA diagnosis were matched in pairs on Expressive Language MSEL age equivalents within two months. The resulting groups were not significantly different on Expressive Language MSEL age equivalent $(t(58)=1.50, p=.138)$. They were about one month apart on Visual Reception MSEL age equivalent $(t(58)=2.04, p=.046)$; the mean Visual Reception age equivalent of the ASD-low MA group was 9.3 months $(S D=2.1)$ and the mean age equivalent of the GDD group was 10.5 months $(S D=2.3)$. The ASD-low MA and GDD groups were also significantly different on chronological age $(t(58)=-2.24, p=.029)$ and Receptive Language MSEL age equivalents $(t(58)=3.74, p<.001)$. The ASD-low MA group was significantly older ( $M=20.4$ months, $S D=5.5)$ than the GDD group ( $M=17.9$ months, $S D=2.8$ ), and the ASD-low MA group had significantly lower Receptive Language MSEL age equivalents ( $M=6.5$ months, $S D=2.4)$ than the GDD group $(M=9.6$ months, $S D=3.8)$. The groups were also 
significantly different on race $(t(52)=2.56, p=.019)$ with more families identifying as White in the ASD-low MA group than the GDD group. Maternal education and sex differences between the groups were not significant.

Children who met criteria for either ASD-low MA or ASD-higher MA were matched on chronological age (CA), resulting in a total of 30 ASD-low MA and 30 ASD-higher MA chronologically age matched children $(t(58)=.13, p=.898)$. Both groups had an average CA of about 20 months (see Table 1). The two ASD groups were significantly different on sex $(t(58)=2.13, p=.037)$, with more male children in the ASD-low MA group $(n=26)$ than the ASDhigher MA group ( $n=19)$. The groups did not significantly differ on race or maternal education.

\section{Overall Cognitive Level}

Overall Mullen Early Learning Composite (ELC) standard scores for the three groups are shown in Table 1. All three groups were below the average range. The ASD-low MA group had the lowest ELC (54.2), which was significantly lower than the GDD group (62.2) and the ASD higher MA group (70.1).

\section{Measures}

\section{Mullen Scales of Early Learning (MSEL; Mullen, 1995)}

The MSEL is a norm-referenced, standardized instrument for assessing cognitive and motor abilities in infants and young children from birth through 68 months. The MSEL contains five scales: Visual Reception, Fine Motor, Expressive Language, Receptive Language, and Gross Motor. The current dataset includes information on the first four scales. The MSEL has excellent reliability, with a median split-half internal consistency of above 0.80 for Expressive Language, Receptive Language, and Gross Motor scales, 0.79 for the Visual Reception scale, and 0.75 for 
the Fine Motor scale. The MSEL manual reports good test-retest reliability of 0.80 after two weeks, and 0.70 after two years (Mullen, 1990).

Bishop, Guthrie, Coffing, \& Lord (2011) established high convergent validity of the MSEL with the Differential Ability Scales $-2^{\text {nd }}$ edition (DAS-II; Elliott, 2007). Bishop et al. (2011) also established excellent discriminant validity between MSEL Verbal standard scores and the MSEL Nonverbal standard scores, suggesting that the MSEL's Expressive and Receptive Language domains validly capture verbal skills while the Visual Reception and Fine Motor domains validly capture nonverbal skills. Positive correlations between MSEL scores and the level of engagement of children with ASD during testing, and negative correlations between MSEL scores and off-task behaviors, emphasize the importance of examiners redirecting children with ASD while maintaining good rapport (Akshoomoff, 2006).

Autism Diagnostic Observation Schedule $-2^{\text {nd }}$ Edition (ADOS-2; Lord et al., 2012)

The ADOS-2 is a semi-structured, standardized assessment of communication, social interaction, and play skills designed to diagnose symptoms of ASD across ages (from 12 months through adulthood) and language abilities. The ADOS-2 has five different modules, including a Toddler Module. The specific module is chosen by the clinician, based on the individual's language level. Given the finding from Miller et al. (2019) suggesting that Module 1 of the ADOS misclassifies children with a low mental age as having ASD when their "true" diagnosis is GDD, the current project examined symptoms in low mental age groups with and without ASD (ASD-low MA and GDD) using the Toddler Module of the ADOS-2 (Lord et al., 2012). The Toddler module is designed for children 12-30 months of age who do not consistently use phrase speech. It is split into two separate scoring algorithms based on whether the child has few to no words, or some words. The ADOS-2 generates two domains based on item-level algorithm 
scores: Social Affect (SA) and Restricted and Repetitive Behavior (RRB). The validation study of the ADOS-2 reported Chronbach's alpha levels for the Toddler Module that are high (0.880.90) for the SA domain and moderate (0.50) for the RRB domain (McCrimmon \& Rostad, 2014). The Toddler Module of the ADOS-2 has high inter-rater reliability, with agreement on diagnostic classifications ranging from $87 \%$ to $97 \%$ (Lord et al., 2012; McCrimmon \& Rostad, 2014).

Exploratory factor analysis of the Toddler Module demonstrated that chronological age and verbal mental age do not significantly contribute to the two separate algorithms once the items were separated by the child's language level. This suggests that the items included in the diagnostic algorithm load onto the factor of autism symptomatology separately from the child's chronological age or verbal mental age (Luyster et al., 2009). All of the items from the SA and RRB domains correlated more strongly with items included in their domain than in items from the other domain. Sensitivity and specificity data on the Toddler Module indicate high levels of predictive validity, above $86 \%$.

\section{Modified Checklist for Autism in Toddlers - Revised with Follow-up (M-CHAT-R/F; Robins et al., 2014)}

The M-CHAT-R/F is one of the most widely used ASD screening tools for toddlers. It is freely available and requires little time on the part of the parent or clinician. The original validation study of the M-CHAT used discriminant function analysis to examine the M-CHAT's

ability to accurately classify children as ASD versus non-ASD (Robins et al., 2001). Robins et al. (2001) demonstrated that 33 out of 38 children with ASD were correctly classified using the MCHAT. The newest version of the M-CHAT (M-CHAT-R/F) includes revisions that eliminated 
three of the original items and added a revised follow-up interview conducted with parents if a child fails more than three items.

The M-CHAT-R/F consists of 20 yes/no parent report items that capture a range of early warning signs of ASD, such as response to name, initiating joint attention, responsive social smiling, and sharing interests with other people. Based on the cutoff of failing three items, the sensitivity of the M-CHAT-R/F is $66.7 \%$, the specificity is $99.5 \%$, the positive predictive value for ASD is 50.9\%, and the negative predictive value is $99.7 \%$ (Robins et al., 2014).

\section{Data Analysis Plan}

The data analysis plan is to identify the behaviors that differed between ASD low-MA group and the GDD group, which are presumed to reflect ASD rather than developmental delay, and to separately see which behaviors differed between the ASD low-MA group and the ASD higher MA group, which presumably reflect developmental level. We examined specific ASD symptoms on screening and diagnostic instruments using chi-square analyses of item-level data. Due to the multiple comparisons between groups, we tried two different corrections which are both reported. Holm-Bonferroni adjustments were made to Fisher's exact p-values to control for the number of comparisons between groups. In order not to over-correct, we also report all comparisons that were significant at $\mathrm{p}<.01$

If a nonverbal or demographic variable differentiated the two groups being compared, logistic regressions were conducted for all significant items controlling for these factors. The ASD low-MA group and GDD groups were not significantly different on MSEL Expressive Language, which was the matching variable, but were significantly different on MSEL Visual Reception with age equivalents differing by about one month. Visual Reception age equivalent was included as a covariate in logistic regressions for the ASD-low MA versus GDD comparison 
so that they would be matched on a language variable and analyses would be controlled for a nonverbal cognitive variable. Race was also included as a covariate in logistic regressions for this comparison since the percentage of people of color in these groups was significantly different.

The ASD-low MA group was comparable to the ASD-higher MA group on chronological age, but differed on developmental level, as expected. The distribution of sex, but not other demographic variables, was also significantly different in these groups, and therefore sex was included as a covariate in logistic regressions for ASD-low MA versus ASD-higher MA comparisons.

The M-CHAT-R/F had 20 items that were already dichotomized. For data from the ADOS-2 Toddler Module, scores of 0 indicated the absence of symptomatic behavior; scores equal to or greater than 1 were collapsed into a single category to indicate the presence of the ASD symptom.

\section{Results}

\section{Autism vs. Non-autism Comparison (ASD-low MA versus GDD) M-CHAT-R/F Comparison}

The ASD-low MA group and GDD group did not significantly differ in their total MCHAT-R/F score $(t(52)=-1.56, p=.125$; Table 1$)$. The ASD-low MA group had an average total score of 7.9 items failed (screened positive) out of a possible 20 ( $S D=5.3$ ); the GDD group had an average total score of $5.9(S D=3.6)$. Chi-square analyses were conducted to identify the percentage of each group that failed each M-CHAT-R/F item. None of the $20 \mathrm{M}-\mathrm{CHAT}-\mathrm{R} / \mathrm{F}$ items remained significant after correcting for multiple comparisons using the Holm-Bonferroni 
method, but three were individually significant at the $p<.01$ level (Table 2). The ASD-low MA group followed a point less often, showed less interest in other children and had less imitation.

Logistic regressions were run for the three significant items with race and visual reception age equivalent as covariates (see Table 2 for adjusted odds ratios and confidence intervals). After controlling for race and visual reception, following a point and showing interest in other children remained significantly less likely at $\mathrm{p}<.01$ in the ASD-low MA group.

\section{ADOS-2 Toddler Module Comparison}

Chi-square analyses were conducted to identify the percentage of each group for whom clinicians endorsed atypical behavior. Out of 41 ADOS-2 items, 19 differed when comparing children with ASD-low MA to those with GDD after setting $p<.01 ; 17$ remained significant after controlling for multiple comparisons with the Holm-Bonferroni method (Table 3). Children with ASD-low MA directed less spontaneous vocalizations to the examiner, more frequently engaged in undirected vocalizations and undirected facial expressions, showed poorly modulated, inconsistent, or avoidant eye contact, coordinated gaze with other behaviors less, showed less pleasure or enjoyment during the interaction, quality of rapport with examiner (not significant with Holm-Bonferroni correction), displayed inconsistent communicative behaviors when the examiner appeared unable to complete a play activity (ADOS-2 item: unable toy play), responded to their name less often, did not integrate requesting with other forms of communication, shared objects with others less, spontaneously initiated less joint attention with the examiner, and used significantly more unusual or inappropriate social overtures.

In the repetitive behaviors domain, children with ASD-low MA showed more unusual sensory interests than children with GDD, engaged in more complex mannerisms and repetitive movements of the hands/fingers and the whole body, and engaged in more frequent repetitive 
interests or stereotyped play. Children with ASD-low MA were also more overreactive (not significant with Holm-Bonferroni correction).

Logistic regressions were run on all significant items with race and visual reception skills as covariates (see Table 3 for adjusted odds ratios and confidence intervals). The following items remained significant: frequency of undirected vocalizations, unusual eye contact, lack of shared enjoyment, quality of rapport with examiner, lack of response to name, less requesting behaviors, responding to a socially ambiguous situation during toy play, lack of spontaneous initiation of joint attention, unusual sensory interests, unusual hand, finger, or body movements, repetitive interests, stereotyped behaviors, and overactivity. Items that were no longer significant after controlling for race and visual reception skills were: frequency of spontaneous vocalizations directed to others, facial expressions directed to others, integration of gaze with other behaviors, giving for the purpose of sharing, and quality of social overtures.

\section{ASD Comparison by Developmental Level (ASD-low MA versus ASD-higher MA) M-CHAT-R/F Comparison}

The ASD-low MA group and ASD-higher MA group did not significantly differ in their total M-CHAT-R/F score of number of items failed $(t(53)=-1.77, p=.083$; Table 1$)$. The ASDlow MA group had an average total score of $7.9(S D=5.3)$, while the ASD-higher MA group had an average total score of $5.7(S D=3.6)$.

Chi-square analyses were used to identify the percentage of each group that failed each M-CHAT-R/F item. Two of the 20 M-CHAT-R/F items differed by diagnostic group when comparing children with ASD-low MA to children with ASD-higher MA, after correcting for multiple comparisons using the Holm-Bonferroni method (Table 4). No items were significant at the $p<.01$ level that did not remain significant with the Holm-Bonferroni correction. The ASD- 
low MA group were less likely to show items to others and to imitate others. In logistic regressions with sex as a covariate, showing items and imitating others remained significantly less likely in the ASD-low MA group (see Table 4 for adjusted odds ratios and confidence intervals). The remaining $18 \mathrm{M}-\mathrm{CHAT}-\mathrm{R} / \mathrm{F}$ items were not significantly different between the ASD-low MA group and the ASD-higher MA group.

\section{ADOS-2 Toddler Module Comparison}

Chi-square analyses were used to identify the percentage of each group for whom clinicians endorsed typical behavior (or a score of 0 ) vs. atypical behavior (score of 1 or higher). Three ADOS-2 items differed by group when comparing children with ASD-low MA to children with ASD-higher MA after controlling for multiple comparisons with the Holm-Bonferroni method (Table 5). No items were significant at the $p<.01$ level that did not remain significant with the Holm-Bonferroni correction. Children in the ASD-low MA group were less likely to respond to joint attention (i.e., the examiner's use of gaze and/or pointing to draw the child's attention to an object in the distance), were less likely to spontaneously initiate joint attention with the examiner, and were significantly more likely to display inconsistent communicative behaviors toward the examiner in a socially ambiguous situation in which the examiner appeared unable to complete a play activity (unable toy play).

In logistic regressions with sex as a covariate and adjusting for multiple comparisons using the Holm-Bonferroni method, these three items remained significant (see Table 5 for adjusted odds ratios and confidence intervals).

\section{Discussion}

There may be specific behaviors that best differentiate ASD-low MA from GDD when screening children with known significant delays for possible ASD. Following a point and 
interest in peers, and perhaps imitation, may be the most robust behaviors that differentiate these two groups on screening instruments when cognitive level is below one year. The remaining MCHAT-R/F items may not be particularly sensitive measures of ASD symptoms in children who are severely developmentally delayed, as they did not occur at significantly different rates in the two groups (Table 2). It is notable that most of the social communication items (not the foil items, such as walking) did show higher frequencies of failure in the ASD-low MA group, but the three that were significant at $p<.01$ showed large discrepancies between the groups that are likely to be clinically significant (following a point: $22.2 \%$ GDD vs. $51.9 \%$ ASD-low MA; interest in peers: $7.4 \%$ vs. $40.7 \%$; imitation: $7.7 \%$ vs. $44.4 \%$ ).

With regard to direct observation, clinicians reported more specific behaviors on the ADOS-2 that differentiated the groups than were apparent on the parent report screener. Since the ASD-low MA and GDD groups were not matched on nonverbal cognition or race, these were controlled for. The remaining significant differences can be grouped into communication (frequency of undirected vocalizations, less requesting behavior, lack of spontaneous initiation of joint attention, and response to name), social responsiveness (unusual eye contact, lack of shared enjoyment, poor responding to a socially ambiguous situation during toy play), unusual sensory interests, repetitive body movements (unusual hand, finger or body finger movements, and complex body mannerisms) and stereotyped interests. The current results suggest that these behaviors are valid diagnostic markers of ASD that distinguish ASD from GDD even in children who are functioning below a one-year level. Behaviors that showed large and clinically significant differences can be seen in Table 4; the biggest differences were on impaired requesting (33.3\% in GDD and 92.9\% in ASD-low MA) and impaired responding to name (33.3\% in GDD and $89.3 \%$ in ASD-low MA). 
Contrary to some literature, including our own (Barton et al., 2013; Troyb et al., 2016), suggesting that repetitive behaviors become more apparent in somewhat older children (Stone et al., 1999) and may not be a valid characterization of very young children with ASD, behaviors in this domain strongly differentiated the GDD and ASD-low MA groups (see Table 4). For example, unusual sensory interests occurred in $28.6 \%$ of the GDD group and $75 \%$ of the ASDlow MA group; complex movements in $33.3 \%$ of the GDD group vs. $75 \%$ of the ASD-low MA group; stereotyped interests in $25 \%$ of the GDD group compared to $71.4 \%$ of the ASD-low MA group. These findings are in line with work suggesting that atypical object use and visual exploration may be an early marker of ASD (Ozonoff et al., 2008).

There were a number of items on the ADOS-2 that were not significantly different between children with GDD and those with ASD-low MA (Table 3). To a certain extent, this replicates prior findings that children with GDD demonstrate impairments in pointing and imagination/creative play (Miller et al., 2019), which may require more advanced cognitive skills. In addition to the items identified by Miller et al. (2019), the current results suggest that children with GDD demonstrated diminished gestures, showing items, and imitation. These items occurred at similar rates in both groups, suggesting that they may not be reliable markers of ASD in children who are very developmentally delayed, but may reflect the delay itself. These behaviors are important for clinicians to consider when diagnosing ASD in children with a low mental age or who present as quite globally delayed.

It is also noteworthy that the GDD children had high rates of impairment on many social communication items (e.g., reduced babbling $85.7 \%$, reduced pointing $84.6 \%$, reduced gestures $85.2 \%$, reduced showing $85.2 \%$ ) as well as functional play $(88.9 \%)$ and creative play $(92.6 \%)$. One potential explanation for this is that the GDD group may not be representative of the broader 
group of children with GDD, since all children included in the study were flagged for ASD risk either through a screening instrument or pediatrician concern. This suggests that the GDD sample included in this study might have higher rates of social communication impairments than would be identified in a broader group of children with GDD.

Other behaviors that may be more indicative of developmental delay than ASD were those that were significantly different between ASD-low MA and ASD-higher MA groups. While the total M-CHAT-R/F score did not differ between these groups, parents of children with ASD and a low mental age endorsed fewer imitation and showing behaviors than parents of children with ASD and a higher mental age. These skills both require motor coordination, as well as concepts of other people as social interaction partners. While these items may be significant markers of low mental age rather than ASD on a screening instrument, neither imitation nor showing items was significantly different between the groups on the ADOS-2. This suggests that parents and clinicians may be observing or interpreting different types of imitation and showing behaviors.

On the ADOS-2, which uses clinician observation, there was a striking lack of behaviors that differentiated the low MA and higher MA ASD groups. Both groups showed very high rates of symptoms on the Toddler Module of the ADOS-2, confirming that this diagnostic instrument is sensitive to ASD in both of these groups. It should be remembered, however, that even the higher MA group had mental age equivalents that were only 12 to 17 months, which is lower than would be expected given their chronological age. Since only three ADOS-2 items were significantly different between the ASD-low MA and ASD-higher MA groups, it is possible that mental age (within the range of the groups in the current study) does not significantly affect the presentation of ASD symptoms in this toddler age group. The only symptoms that differentiated 
the two groups were inconsistent communication in an ambiguous situation and joint attention (both responding and initiating); joint attention symptoms were endorsed for only about half of the ASD-higher MA group, but almost all of the ASD-low MA group. Since joint attention is such a central symptom of ASD (Charman, 2003), it may be that the ADOS-2 provides enough structure and opportunity that it elicits more joint attention than may be seen in everyday life.

In line with previous literature (Kim \& Lord, 2010; Wolff et al., 2014), the presence of restricted and repetitive behaviors may discriminate groups of children with ASD from groups of children with other developmental delays regardless of a child's mental age. ADOS-2 items related to restricted and repetitive behaviors occurred in significantly more children with ASDlow MA compared to children with GDD, but these behaviors occurred at similarly high rates in both ASD groups. These behaviors may be a useful diagnostic marker of ASD in toddlers with low mental ages.

Items that were significantly different in the ASD-low MA group compared to both the GDD group and the ASD-higher MA group are potential indicators of a unique ASD-low MA phenotype combining developmental delay and ASD symptoms. These items were joint attention, both initiation and response, and responding to a socially ambiguous situation during toy play. These nuanced social behaviors reflect theory of mind concepts and may require more advanced cognitive skills. In both the joint attention ADOS-2 item and the socially ambiguous play item, the child must intentionally direct the examiner's attention or attribute intention to the examiner. Various theories have suggested that the initiation of and response to joint attention may reflect similar cognitive and social processes, while others have pointed out differences in the predictive value, neuropsychological underpinnings, and relationships to early executive processes when comparing initiation and response to joint attention (Vaughan Van Hecke et al., 
2007). Various reviews of the literature on typical development and ASD (e.g., Charman, 2003;

Naber et al., 2007) have shown that basic joint attention skills, including pointing, showing, point and gaze following, show strong development between six and 12 months in typical infants. It is notable that the ASD-higher MA group had cognitive skills at or above 12 months, while both GDD and ASD-low MA had cognitive skills between six and 12 months. It is quite reasonable to suppose that both cognitive delay and ASD contribute separately to initiating and responding to joint attention, as suggested by others (Mundy et al., 1994; Paparella et al., 2011). This is consistent with our findings that joint attention differs between our ASD groups with age equivalents above and below 12 months. Developmental delays, especially in children with severe delays, undoubtedly exacerbate social cognition difficulties in children with ASD.

There are several limitations to the current study. A major limitation is that some items have extremely wide confidence intervals. For example, only one child in the ASD-higher MA group failed the imitation item on the M-CHAT-R/F, compared to almost $50 \%$ of the ASD-low MA group, resulting in a very wide confidence interval. These wide confidence intervals impact the reliability of these estimates and should be interpreted with caution.

Another limitation is that the groups were not perfectly matched on chronological age or cognitive functioning. Even within a single diagnostic group the standard deviation on MSEL age equivalents is 2-3 months, which is a meaningful amount of scatter in children who are functioning at a six- to nine-month level. The ASD-low MA group and the GDD group were about one month different on visual reception and expressive language skills but were three months different on their receptive language abilities. Although we matched the groups as closely as possible given the sample characteristics, the matching was not perfect. It is important to note that the ASD-low MA sample was particularly delayed; the group's chronological age 
was around 20 months, but their receptive language was at the level of a six-month old. The ASD-low MA group was also chronologically three months older than the GDD group but had lower receptive language skills. Receptive language skills were low for both groups (GDD mean $=9.6$ months; ASD-low MA mean = 6.5 months) compared to their chronological age. These low receptive language skills indicate that children in both groups may be inattentive to voices and sounds, and are still at very early stages of actual receptive language comprehension.

In addition, the ASD-higher MA group did not meet criteria for low MA but were still not functioning within the average range of development (see Table 1 for MSEL Early Learning Composite standard scores). Comparing severely delayed children with ASD to those within or close to a normal range of development in some domains would doubtless produce increased differences between groups. Furthermore, although the literature suggests that greater ASD severity and cognitive delays tend to even out the sex ratio in ASD (Lai et al., 2015), our participants suggested the opposite: there were more boys in the ASD-low MA group than the ASD-higher MA group, suggesting that there might be something unique about our sample.

Another limitation within the developmental comparison is that race was unequally distributed in these groups; significantly more people of color had a GDD diagnosis. Prior research (Mandell et al., 2009) indicates that people of color are significantly less likely to have a documented ASD diagnosis than White children, and that providers are less likely to assess for ASD in children of color who have a documented intellectual disability or global delay. It is possible that screening and diagnostic items function differently in these groups. Since children came to the evaluation from a positive screen or from pediatrician concern, it is possible that social factors causing lower and later ASD diagnoses in the general population were at play in 
identifying which children were referred for evaluation. However, once at the evaluation, procedures were consistent for all groups.

Results indicated that the ADOS-2 Toddler Module successfully captured ASD symptomatology even in children whose mental age is below 12 months. Symptomatology in the low MA and higher MA ASD groups was strikingly similar. Contrary to some prior literature, unusual interests and repetitive behaviors were seen in these low MA ASD children.

Developmental level affected the clinical presentation of ASD less than was expected, except that initiating and responding to joint attention was more affected in the low MA group. Comparing the ASD-low MA children to ASD children with development within the normal range may produce a clearer set of differences. Additionally, many behaviors distinguished children with ASD-low MA from children with GDD in all ASD domains (communication, social interaction, repetitive behaviors), supporting the conclusion that ASD can be validly diagnosed in children with mental ages under 12 months. This is important information for clinicians to consider in evaluating globally delayed toddlers who present with ASD features. 
Table 1

Participant Characteristics by Diagnostic Group

\begin{tabular}{|c|c|c|c|c|c|}
\hline Variable & $\begin{array}{l}\text { GDD } \\
(n=30)\end{array}$ & $\begin{array}{l}\text { ASD-low } \\
\text { MA } \\
(n=30)\end{array}$ & $\begin{array}{l}\text { ASD- } \\
\text { higher MA } \\
(n=30)\end{array}$ & $\begin{array}{l}p \\
\text { (ASD-low } \\
\text { MA vs } \\
\text { GDD) }\end{array}$ & $\begin{array}{l}p \\
\text { (ASD-low } \\
\text { MA vs ASD- } \\
\text { higher MA) }\end{array}$ \\
\hline Age in months $[M(S D)]$ & $\begin{array}{l}17.9 \\
(2.8)\end{array}$ & $20.4(5.5)$ & $20.6(5.4)$ & .029 & .898 \\
\hline $\operatorname{Sex}[n(\%)]$ & & & & .121 & .037 \\
\hline Male & $\begin{array}{l}21 \\
(70 \%)\end{array}$ & $26(86.7 \%)$ & $19(63.3 \%)$ & & \\
\hline Female & $9(30 \%)$ & $4(13.3 \%)$ & $11(36.7 \%)$ & & \\
\hline Race & & & & .019 & .179 \\
\hline White & $\begin{array}{l}8 \\
(29.6 \%)\end{array}$ & $17(63 \%)$ & $12(44.4 \%)$ & & \\
\hline People of color & $\begin{array}{l}19 \\
(70.4 \%)\end{array}$ & $10(37 \%)$ & $15(55.6 \%)$ & & \\
\hline $\begin{array}{l}\text { Maternal education } \\
{[n(\%)]}\end{array}$ & & & & .730 & .614 \\
\hline $\begin{array}{r}\text { Less than high school } \\
\text { diploma }\end{array}$ & $\begin{array}{l}4 \\
(14.3 \%)\end{array}$ & $2(6.7 \%)$ & $0(0 \%)$ & & \\
\hline $\begin{array}{r}\text { High school } \\
\text { diploma/GED }\end{array}$ & $\begin{array}{l}6 \\
(21.4 \%)\end{array}$ & $13(43.3 \%)$ & $14(46.7 \%)$ & & \\
\hline $\begin{array}{r}\text { Vocational or technical } \\
\text { degree }\end{array}$ & $\begin{array}{l}7 \\
(25.0 \%)\end{array}$ & $2(6.7 \%)$ & $3(10 \%)$ & & \\
\hline Associate degree & $2(7.1 \%)$ & $5(16.7 \%)$ & $3(10 \%)$ & & \\
\hline Bachelor's degree & $\begin{array}{l}4 \\
(14.3 \%)\end{array}$ & $5(16.7 \%)$ & $5(16.7 \%)$ & & \\
\hline Advanced degree & $\begin{array}{l}5 \\
(17.8 \%)\end{array}$ & $3(10 \%)$ & $5(16.7 \%)$ & & \\
\hline $\begin{array}{l}\text { Total M-CHAT-R/F } \\
\text { score } \\
{[M(S D)]}\end{array}$ & $5.9(3.6)$ & $7.9(5.3)$ & $5.7(3.6)$ & .125 & .083 \\
\hline $\begin{array}{l}\text { MSEL Early Learning } \\
\text { Composite standard } \\
\text { score }[M(S D)]\end{array}$ & $\begin{array}{l}62.2 \\
(10.2)\end{array}$ & $54.2(7.5)$ & $70.1(15.2)$ & $<.001$ & $<.001$ \\
\hline \multicolumn{6}{|l|}{$\begin{array}{l}\text { MSEL age equivalent in } \\
\text { months }[M(S D)]\end{array}$} \\
\hline Expressive language & $8.8(3.6)$ & $7.7(2.3)$ & $12.7(4.8)$ & .138 & $<.001$ \\
\hline Visual reception & $\begin{array}{l}10.5 \\
(2.3)\end{array}$ & $9.3(2.2)$ & $16.1(3.4)$ & .046 & $<.001$ \\
\hline Receptive language & $9.6(3.9)$ & $6.5(2.4)$ & $12.1(4.2)$ & $<.001$ & $<.001$ \\
\hline
\end{tabular}


Table 2

Number of Children by Group who Failed M-CHAT-R/F Items (GDD versus ASD-low MA)

\begin{tabular}{|c|c|c|c|c|}
\hline $\begin{array}{l}\text { M-CHAT- } \\
\text { R/F Item }\end{array}$ & $\begin{array}{l}\text { GDD } \\
\text { Group } \\
n(\%)\end{array}$ & $\begin{array}{c}\text { ASD-low } \\
\text { MA Group } \\
n(\%)\end{array}$ & $\begin{array}{c}\text { Chi-square } \\
\text { (*: significant at } \\
\text { p<.01 level) } \\
\text { unadjusted for race } \\
\text { and visual reception }\end{array}$ & $\begin{array}{c}\text { AOR } \\
(\mathbf{9 5 \%} \mathbf{C I}) \text { adjusted for } \\
\text { race and visual } \\
\text { reception }\end{array}$ \\
\hline $\begin{array}{l}\text { Item } 1 \text { (follows a } \\
\text { point) }\end{array}$ & $4(22.2 \%)$ & $14(51.9 \%)$ & $8.33^{*}(p=.008)$ & $\begin{array}{c}7.50 \\
(1.51-37.21) \\
\end{array}$ \\
\hline $\begin{array}{l}\text { Item } 2 \text { (wondered } \\
\text { if deaf) }\end{array}$ & $1(3.7 \%)$ & $4(14.8 \%)$ & $1.98(p=.351)$ & \\
\hline $\begin{array}{l}\text { Item } 3 \text { (pretend } \\
\text { play) }\end{array}$ & $\begin{array}{c}15 \\
(55.6 \%)\end{array}$ & $17(63 \%)$ & $0.31(p=.782)$ & \\
\hline $\begin{array}{l}\text { Item } 4 \text { (enjoys } \\
\text { climbing) }\end{array}$ & $6(22.2 \%)$ & $4(14.8 \%)$ & $0.49(p=.728)$ & \\
\hline $\begin{array}{l}\text { Item } 5 \text { (unusual } \\
\text { finger } \\
\text { movements) }\end{array}$ & $6(22.2 \%)$ & $4(14.8 \%)$ & $0.49(p=.728)$ & \\
\hline $\begin{array}{l}\text { Item } 6 \text { (points to } \\
\text { request) }\end{array}$ & $\begin{array}{c}17 \\
(63.0 \%) \\
\end{array}$ & $19(70.4 \%)$ & $0.33(p=.773)$ & \\
\hline $\begin{array}{l}\text { Item } 7 \text { (points to } \\
\text { show) }\end{array}$ & $\begin{array}{c}17 \\
(63.0 \%) \\
\end{array}$ & $21(77.8 \%)$ & $1.42(p=.372)$ & \\
\hline $\begin{array}{l}\text { Item } 8 \text { (interest } \\
\text { in other children) }\end{array}$ & $2(7.4 \%)$ & $11(40.7 \%)$ & $8.21 *(p=.009)$ & $\begin{array}{c}7.99 \\
(1.25-50.94) \\
\end{array}$ \\
\hline $\begin{array}{l}\text { Item } 9 \text { (shows } \\
\text { items) }\end{array}$ & $\begin{array}{c}14 \\
(51.9 \%)\end{array}$ & $17(63.0 \%)$ & $0.68(p=.583)$ & \\
\hline $\begin{array}{l}\text { Item } 10 \text { (responds } \\
\text { to name) }\end{array}$ & $3(11.5 \%)$ & $9(33.3 \%)$ & $3.60(\mathrm{p}=.099)$ & \\
\hline $\begin{array}{l}\text { Item } 11 \text { (social } \\
\text { smiling) }\end{array}$ & $0(0 \%)$ & $4(14.8 \%)$ & $4.32(p=.111)$ & \\
\hline $\begin{array}{l}\text { Item } 12 \text { (upset by } \\
\text { everyday noises) }\end{array}$ & $7(25.9 \%)$ & $5(18.5 \%)$ & $0.43(p=.745)$ & \\
\hline $\begin{array}{l}\text { Item } 13 \text { (does } \\
\text { child walk) }\end{array}$ & $\begin{array}{c}15 \\
(55.6 \%) \\
\end{array}$ & $7(26.9 \%)$ & $4.47(p=.051)$ & \\
\hline $\begin{array}{l}\text { Item } 14 \text { (eye } \\
\text { contact) }\end{array}$ & $3(11.1 \%)$ & $7(25.9 \%)$ & $1.97(p=.293)$ & \\
\hline $\begin{array}{l}\text { Item } 15 \\
\text { (imitation) }\end{array}$ & $2(7.7 \%)$ & $12(44.4 \%)$ & $9.20 *(p=.004)$ & \\
\hline $\begin{array}{l}\text { Item } 16 \text { (looks at } \\
\text { what you're } \\
\text { looking at) }\end{array}$ & $9(33.3 \%)$ & $12(44.4 \%)$ & $0.70(p=.577)$ & \\
\hline $\begin{array}{l}\text { Item } 17 \text { (tries to } \\
\text { get you to watch } \\
\text { him) }\end{array}$ & $\begin{array}{c}15 \\
(55.6 \%)\end{array}$ & $15(55.6 \%)$ & $0.00(p=1.000)$ & \\
\hline
\end{tabular}




\begin{tabular}{|c|c|c|c|c|}
\hline $\begin{array}{l}\text { M-CHAT- } \\
\text { R/F Item }\end{array}$ & $\begin{array}{c}\text { GDD } \\
\text { Group } \\
n(\%)\end{array}$ & $\begin{array}{c}\text { ASD-low } \\
\text { MA Group } \\
n(\%)\end{array}$ & $\begin{array}{c}\text { Chi-square } \\
\text { (*: significant at } \\
\mathbf{p}<.01 \text { level) } \\
\text { unadjusted for race } \\
\text { and visual reception }\end{array}$ & $\begin{array}{c}\text { AOR } \\
(\mathbf{9 5 \%} \mathbf{C I}) \text { adjusted for } \\
\text { race and visual } \\
\text { reception }\end{array}$ \\
\hline $\begin{array}{l}\text { Item } 18 \text { (follows } \\
\text { directions) }\end{array}$ & $\begin{array}{c}15 \\
(55.6 \%)\end{array}$ & $17(63.0 \%)$ & $0.31(p=.782)$ & \\
\hline $\begin{array}{l}\text { Item } 19 \text { (looks at } \\
\text { your face for } \\
\text { reaction) }\end{array}$ & $8(29.6 \%)$ & $13(48.1 \%)$ & $1.95(p=.264)$ & \\
\hline $\begin{array}{l}\text { Item } 20 \text { (enjoys } \\
\text { movement } \\
\text { activities) }\end{array}$ & $1(3.8 \%)$ & $0(0.0 \%)$ & $1.06(p=.481)$ & \\
\hline
\end{tabular}




\section{Table 3}

Number of Children by Group with Endorsed ADOS-2 Toddler Module Items (GDD versus ASDlow MA)

\begin{tabular}{|c|c|c|c|c|}
\hline $\begin{array}{c}\text { ADOS-2 } \\
\text { Toddler } \\
\text { Module } \\
\text { Item }\end{array}$ & $\begin{array}{c}\text { GDD } \\
\text { Group } \\
n(\%) \\
\text { endorsed } \\
\text { symptom }\end{array}$ & $\begin{array}{c}\text { ASD-low MA } \\
\text { Group } \\
n(\%) \\
\text { endorsed } \\
\text { symptom }\end{array}$ & $\begin{array}{c}\text { Chi-square } \\
\text { (*: significant after } \\
\text { Holm-Bonferroni } \\
\text { correction) } \\
\text { unadjusted for race } \\
\text { and visual reception }\end{array}$ & $\begin{array}{c}\text { AOR } \\
(\mathbf{9 5 \%} \mathbf{C I}) \\
\text { adjusted for race } \\
\text { and visual } \\
\text { reception }\end{array}$ \\
\hline $\begin{array}{l}\text { Al (overall level } \\
\text { of non-echoed } \\
\text { spoken } \\
\text { language) }\end{array}$ & $28(100 \%)$ & $28(100 \%)$ & N/A & \\
\hline $\begin{array}{l}\text { Ala (frequency } \\
\text { of babbling) }\end{array}$ & $24(85.7 \%)$ & $26(92.9 \%)$ & $\begin{array}{c}0.75 \\
(p=.669)\end{array}$ & \\
\hline $\begin{array}{l}\text { A2 (frequency } \\
\text { of spontaneous } \\
\text { vocalizations } \\
\text { directed to } \\
\text { others) }\end{array}$ & $20(71.4 \%)$ & $28(100 \%)$ & $\begin{array}{c}9.33 * \\
(p=.004)\end{array}$ & \\
\hline $\begin{array}{l}\text { A3 (intonation of } \\
\text { vocalizations } \\
\text { and } \\
\text { verbalizations) }\end{array}$ & $3(18.8 \%)$ & $9(52.9 \%)$ & $\begin{array}{c}4.16 \\
(p=.071)\end{array}$ & \\
\hline $\begin{array}{l}\text { A4 (immediate } \\
\text { echolalia) }\end{array}$ & N/A (8's) & N/A (8's) & N/A & \\
\hline $\begin{array}{l}\text { A5 } \\
\text { (stereotyped/idio } \\
\text { syncratic use of } \\
\text { words or } \\
\text { phrases) }\end{array}$ & N/A (8's) & N/A (8's) & N/A & \\
\hline $\begin{array}{l}\text { A6 (use of } \\
\text { another's body) }\end{array}$ & $9(39.1 \%)$ & $16(69.6 \%)$ & $\begin{array}{c}4.29 \\
(p=.075)\end{array}$ & \\
\hline A7 (pointing) & $22(84.6 \%)$ & $28(100 \%)$ & $\begin{array}{c}4.65 \\
(p=.047)\end{array}$ & \\
\hline A8 (gestures) & $23(85.2 \%)$ & $26(100 \%)$ & $\begin{array}{c}4.17 \\
(p=.111)\end{array}$ & \\
\hline $\begin{array}{l}\text { A9 (frequency } \\
\text { of undirected } \\
\text { vocalization) }\end{array}$ & $8(34.8 \%)$ & $22(91.7 \%)$ & $\begin{array}{c}16.46^{*} \\
(p<.001)\end{array}$ & $\begin{array}{c}23.14 \\
(2.57-208.54)\end{array}$ \\
\hline $\begin{array}{l}\text { B1 (unusual eye } \\
\text { contact) }\end{array}$ & $12(42.9 \%)$ & $27(96.4 \%)$ & $\begin{array}{c}19.01 * \\
(p<.001)\end{array}$ & $\begin{array}{c}62.80 \\
(3.95-998.79) \\
\end{array}$ \\
\hline
\end{tabular}




\begin{tabular}{|c|c|c|c|c|}
\hline $\begin{array}{c}\text { ADOS-2 } \\
\text { Toddler } \\
\text { Module } \\
\text { Item }\end{array}$ & $\begin{array}{c}\text { GDD } \\
\text { Group } \\
n(\%) \\
\text { endorsed } \\
\text { symptom }\end{array}$ & $\begin{array}{l}\text { ASD-low MA } \\
\text { Group } \\
n(\%) \\
\text { endorsed } \\
\text { symptom }\end{array}$ & $\begin{array}{c}\text { Chi-square } \\
\text { (*: significant after } \\
\text { Holm-Bonferroni } \\
\text { correction) } \\
\text { unadjusted for race } \\
\text { and visual reception }\end{array}$ & $\begin{array}{c}\text { AOR } \\
(\mathbf{9 5 \%} \mathbf{C I}) \\
\text { adjusted for race } \\
\text { and visual } \\
\text { reception }\end{array}$ \\
\hline $\begin{array}{l}\text { B2 (teasing toy } \\
\text { play) }\end{array}$ & $14(51.9 \%)$ & $19(79.2 \%)$ & $\begin{array}{c}4.15 \\
(p=.077)\end{array}$ & \\
\hline $\begin{array}{l}\text { B3 (unable toy } \\
\text { play) }\end{array}$ & $8(30.8 \%)$ & $23(88.5 \%)$ & $\begin{array}{c}17.97^{*} \\
(p<.001)\end{array}$ & $\begin{array}{c}22.48 \\
(3.01-167.85)\end{array}$ \\
\hline $\begin{array}{l}\text { B4 (facial } \\
\text { expressions } \\
\text { directed to } \\
\text { others) }\end{array}$ & $14(50.0 \%)$ & $28(100 \%)$ & $\begin{array}{l}18.67 * \\
(p<.001)\end{array}$ & \\
\hline $\begin{array}{l}\text { B5 (integration } \\
\text { of gaze and } \\
\text { other behaviors) }\end{array}$ & $17(60.7 \%)$ & $28(100 \%)$ & $\begin{array}{l}13.69 * \\
(p<.001)\end{array}$ & \\
\hline $\begin{array}{l}\text { B6(shared } \\
\text { enjoyment) }\end{array}$ & $6(21.4 \%)$ & $19(67.9 \%)$ & $\begin{array}{c}12.21^{*} \\
(p<.001)\end{array}$ & $\begin{array}{c}12.04 \\
(2.31-62.68)\end{array}$ \\
\hline $\begin{array}{l}\text { B7 (response to } \\
\text { name) }\end{array}$ & $9(33.3 \%)$ & $25(89.3 \%)$ & $\begin{array}{c}18.23 * \\
(p<.001)\end{array}$ & $\begin{array}{c}19.59 \\
(2.82-136.20)\end{array}$ \\
\hline B8 (ignore) & $18(69.2 \%)$ & $24(88.9 \%)$ & $\begin{array}{c}3.11 \\
(p=.099)\end{array}$ & \\
\hline B9 (requesting) & $13(33.3 \%)$ & $29(92.9 \%)$ & $\begin{array}{c}14.28^{*} \\
(p<.001)\end{array}$ & $\begin{array}{c}35.55 \\
(2.89-437.41)\end{array}$ \\
\hline $\begin{array}{l}\text { B10 (amount of } \\
\text { requesting) }\end{array}$ & $23(82.1 \%)$ & $28(100 \%)$ & $\begin{array}{c}5.49 \\
(\mathrm{p}=.051)\end{array}$ & \\
\hline B11 (giving) & $16(61.5 \%)$ & $28(100 \%)$ & $\begin{array}{c}13.22 * \\
(p<.001)\end{array}$ & \\
\hline B12 (showing) & $23(85.2 \%)$ & $28(100 \%)$ & $\begin{array}{c}4.47 \\
(p=.051)\end{array}$ & \\
\hline $\begin{array}{l}\text { B13 } \\
\text { (spontaneous } \\
\text { IJA) }\end{array}$ & $15(53.6 \%)$ & $27(96.4 \%)$ & $\begin{array}{c}13.71^{*} \\
(p<.001)\end{array}$ & $\begin{array}{c}33.52 \\
(2.53-444.92)\end{array}$ \\
\hline $\begin{array}{l}\text { B14 (response to } \\
\text { JA) }\end{array}$ & $18(66.7 \%)$ & $26(96.3 \%)$ & $\begin{array}{c}7.85 \\
(p=.011)\end{array}$ & \\
\hline $\begin{array}{l}\text { B15 (quality of } \\
\text { social overtures) }\end{array}$ & $16(59.3 \%)$ & $28(100 \%)$ & $\begin{array}{c}14.26 * \\
(p<.001)\end{array}$ & \\
\hline $\begin{array}{l}\text { B16a (amount of } \\
\text { social overtures } \\
\text { to examiner) }\end{array}$ & $21(75.0 \%)$ & $28(100 \%)$ & $\begin{array}{c}8.00 \\
(p=.010)\end{array}$ & \\
\hline $\begin{array}{l}\text { B16b (amount of } \\
\text { social overtures } \\
\text { to parent) }\end{array}$ & $20(74.1 \%)$ & $26(92.9 \%)$ & $\begin{array}{c}3.54 \\
(p=.078)\end{array}$ & \\
\hline $\begin{array}{l}\text { B17 (level of } \\
\text { engagement) }\end{array}$ & $18(66.7 \%)$ & $26(96.3 \%)$ & $\begin{array}{c}7.86 \\
(p=.011)\end{array}$ & \\
\hline
\end{tabular}




\begin{tabular}{|c|c|c|c|c|}
\hline $\begin{array}{c}\text { ADOS-2 } \\
\text { Toddler } \\
\text { Module } \\
\text { Item }\end{array}$ & $\begin{array}{c}\text { GDD } \\
\text { Group } \\
n(\%) \\
\text { endorsed } \\
\text { symptom }\end{array}$ & $\begin{array}{c}\text { ASD-low MA } \\
\text { Group } \\
n(\%) \\
\text { endorsed } \\
\text { symptom }\end{array}$ & $\begin{array}{c}\text { Chi-square } \\
\text { (*: significant after } \\
\text { Holm-Bonferroni } \\
\text { correction) } \\
\text { unadjusted for race } \\
\text { and visual reception }\end{array}$ & $\begin{array}{c}\text { AOR } \\
(\mathbf{9 5 \%} \mathbf{C I}) \\
\text { adjusted for race } \\
\text { and visual } \\
\text { reception }\end{array}$ \\
\hline $\begin{array}{l}\text { B18 (quality of } \\
\text { rapport) }\end{array}$ & $15(55.6 \%)$ & $25(92.6 \%)$ & $\begin{array}{c}9.64 \\
(p=.004)\end{array}$ & $\begin{array}{c}9.31 \\
(1.31-66.00)\end{array}$ \\
\hline $\begin{array}{l}\text { Cl (functional } \\
\text { play with } \\
\text { objects) }\end{array}$ & $24(88.9 \%)$ & $28(100 \%)$ & $\begin{array}{c}3.29 \\
(p=.111)\end{array}$ & \\
\hline $\begin{array}{l}\mathrm{C} 2 \\
\text { (imagination/cre } \\
\text { ativity) }\end{array}$ & $25(92.6 \%)$ & $28(100 \%)$ & $\begin{array}{c}2.15 \\
(p=.236)\end{array}$ & \\
\hline $\begin{array}{l}\text { C3 (functional } \\
\text { and symbolic } \\
\text { imitation) }\end{array}$ & $23(82.1 \%)$ & $28(100 \%)$ & $\begin{array}{c}5.49 \\
(p=.051)\end{array}$ & \\
\hline $\begin{array}{l}\text { D1 (unusual } \\
\text { sensory } \\
\text { interests) }\end{array}$ & $8(28.6 \%)$ & $21(75.0 \%)$ & $\begin{array}{c}12.09 * \\
(p=.001)\end{array}$ & $\begin{array}{c}20.00 \\
(3.34-119.54)\end{array}$ \\
\hline $\begin{array}{l}\text { D2 (hand/finger } \\
\text { movements) }\end{array}$ & $3(11.1 \%)$ & $15(53.6 \%)$ & $\begin{array}{c}11.26 * \\
(p=.001)\end{array}$ & $\begin{array}{c}20.98 \\
(2.97-148.12) \\
\end{array}$ \\
\hline $\begin{array}{l}\text { D3 (other } \\
\text { complex } \\
\text { mannerisms) } \\
\end{array}$ & $9(33.3 \%)$ & $21(75.0 \%)$ & $\begin{array}{c}9.63 * \\
(p=.003)\end{array}$ & $\begin{array}{c}9.75 \\
(1.97-48.36)\end{array}$ \\
\hline$D 4(S I B)$ & $3(10.7 \%)$ & $3(10.7 \%)$ & $\begin{array}{c}\text { NA (cell count less } \\
\text { than 5) }\end{array}$ & \\
\hline $\begin{array}{l}\text { D5 (repetitive } \\
\text { interests/stereoty } \\
\text { ped behaviors) }\end{array}$ & $7(25.0 \%)$ & $20(71.4 \%)$ & $\begin{array}{c}12.09 * \\
(p=.001)\end{array}$ & $\begin{array}{c}9.62 \\
(1.96-47.29)\end{array}$ \\
\hline E1 (overactivity) & $10(35.7 \%)$ & $21(75.0 \%)$ & $\begin{array}{c}8.74 \\
(p=.007)\end{array}$ & $\begin{array}{c}12.81 \\
(2.29-71.58)\end{array}$ \\
\hline $\begin{array}{l}\text { E2 } \\
\text { (fussiness/irritab } \\
\text { ility) }\end{array}$ & $10(35.7 \%)$ & $19(67.9 \%)$ & $\begin{array}{c}5.79 \\
(p=.031)\end{array}$ & \\
\hline $\begin{array}{l}\text { E3 (aggression } \\
\text { and disruptive } \\
\text { behavior) }\end{array}$ & $2(7.1 \%)$ & $1(3.6 \%)$ & $\begin{array}{c}\text { NA (cell count less } \\
\text { than } 5)\end{array}$ & \\
\hline E4 (anxiety) & $8(28.6 \%)$ & $6(21.4 \%)$ & $\begin{array}{c}.38 \\
(p=.758)\end{array}$ & \\
\hline
\end{tabular}




\section{Table 4}

Number of Children by Group who Failed M-CHAT-R/F Items (ASD higher-MA versus ASD-low MA)

\begin{tabular}{|c|c|c|c|c|}
\hline $\begin{array}{l}\text { M-CHAT-R/F } \\
\text { Item }\end{array}$ & $\begin{array}{c}\text { ASD- } \\
\text { higher MA } \\
\text { group } \\
n(\%)\end{array}$ & $\begin{array}{l}\text { ASD-low } \\
\text { MA group } \\
n(\%)\end{array}$ & $\begin{array}{c}\text { Chi-square } \\
\text { (*: significant } \\
\text { after Holm- } \\
\text { Bonferroni } \\
\text { correction) } \\
\text { unadjusted for sex }\end{array}$ & $\begin{array}{c}\text { AOR } \\
(\mathbf{9 5 \%} \mathbf{C I}) \\
\text { adjusted for sex }\end{array}$ \\
\hline $\begin{array}{c}\text { Item } 1 \text { (follows a } \\
\text { point) }\end{array}$ & $8(28.6 \%)$ & $14(51.9 \%)$ & $3.10(p=.102)$ & \\
\hline $\begin{array}{c}\text { Item } 2 \text { (wondered } \\
\text { if deaf) }\end{array}$ & $4(14.3 \%)$ & $4(14.8 \%)$ & $0.00(p=1.000)$ & \\
\hline $\begin{array}{c}\text { Item } 3 \text { (pretend } \\
\text { play) }\end{array}$ & $9(32.1 \%)$ & $17(63 \%)$ & $5.24(p=.031)$ & \\
\hline $\begin{array}{c}\text { Item } 4 \text { (enjoys } \\
\text { climbing) }\end{array}$ & $0(0 \%)$ & $4(14.8 \%)$ & $4.47(p=.051)$ & \\
\hline $\begin{array}{c}\text { Item } 5 \text { (unusual } \\
\text { finger } \\
\text { movements) }\end{array}$ & $9(32.1 \%)$ & $4(14.8 \%)$ & $2.29(p=.205)$ & \\
\hline $\begin{array}{c}\text { Item } 6 \text { (point to } \\
\text { request) }\end{array}$ & $18(64.3 \%)$ & $19(70.4 \%)$ & $0.23(p=.775)$ & \\
\hline $\begin{array}{c}\text { Item } 7 \text { (point to } \\
\text { show) }\end{array}$ & $18(64.3 \%)$ & $21(77.8 \%)$ & $1.21(p=.375)$ & \\
\hline $\begin{array}{c}\text { Item } 8 \text { (interest in } \\
\text { other children) }\end{array}$ & $4(14.8 \%)$ & $11(40.7 \%)$ & $4.52(p=.066)$ & \\
\hline $\begin{array}{c}\text { Item } 9 \text { (show } \\
\text { items) }\end{array}$ & $6(21.4 \%)$ & $17(63 \%)$ & $9.75^{*}(p=.003)$ & $\begin{array}{c}6.000 \\
(1.79-20.15) \\
\end{array}$ \\
\hline $\begin{array}{c}\text { Item } 10 \text { (respond } \\
\text { to name) }\end{array}$ & $6(21.4 \%)$ & $9(33.3 \%)$ & $0.98(p=.375)$ & \\
\hline $\begin{array}{c}\text { Item } 11 \text { (social } \\
\text { smiling) }\end{array}$ & $2(7.1 \%)$ & $4(14.8 \%)$ & $0.83(p=.422)$ & \\
\hline $\begin{array}{l}\text { Item } 12 \text { (upset by } \\
\text { everyday noises) }\end{array}$ & $10(37 \%)$ & $5(18.5 \%)$ & $2.31(p=.224)$ & \\
\hline $\begin{array}{l}\text { Item } 13 \text { (does } \\
\text { child walk) }\end{array}$ & $1(3.7 \%)$ & $7(26.9 \%)$ & $5.57(p=.024)$ & \\
\hline $\begin{array}{c}\text { Item } 14 \text { (eye } \\
\text { contact) }\end{array}$ & $6(21.4 \%)$ & $7(25.9 \%)$ & $0.15(p=.758)$ & \\
\hline $\begin{array}{c}\text { Item } 15 \\
\text { (imitation) }\end{array}$ & $1(3.6 \%)$ & $12(44.4 \%)$ & $12.72 *(p<.001)$ & $\begin{array}{c}46.98 \\
(3.40-650.06)\end{array}$ \\
\hline
\end{tabular}




\begin{tabular}{|c|c|c|c|c|}
\hline $\begin{array}{c}\text { M-CHAT-R/F } \\
\text { Item }\end{array}$ & $\begin{array}{c}\text { ASD- } \\
\text { higher MA } \\
\text { group } \\
\mathbf{n}(\boldsymbol{\%})\end{array}$ & $\begin{array}{c}\text { ASD-low } \\
\text { MA group } \\
\boldsymbol{n}(\boldsymbol{\%})\end{array}$ & $\begin{array}{c}\text { Chi-square } \\
\text { (*: significant } \\
\text { after Holm- } \\
\text { Bonferroni } \\
\text { correction) } \\
\text { unadjusted for sex }\end{array}$ & $\begin{array}{c}\text { AOR } \\
\text { (95\% CI) } \\
\text { adjusted for sex }\end{array}$ \\
\hline $\begin{array}{c}\text { Item 16 (look at } \\
\text { what you're } \\
\text { looking at) }\end{array}$ & $15(53.6 \%)$ & $12(44.4 \%)$ & $0.46(p=.593)$ & \\
\hline $\begin{array}{c}\text { Item 17 (try to get } \\
\text { you to watch him) }\end{array}$ & $16(57.1 \%)$ & $15(55.6 \%)$ & $0.01(p=1.000)$ & \\
\hline $\begin{array}{c}\text { Item 18 (follow } \\
\text { directions) }\end{array}$ & $14(50.4 \%)$ & $17(63.0 \%)$ & $0.94(p=.418)$ & \\
\hline $\begin{array}{c}\text { Item 19 (look at } \\
\text { your face for } \\
\text { reaction) }\end{array}$ & $10(37.0 \%)$ & $13(48.1 \%)$ & $0.68(p=.583)$ & \\
\hline $\begin{array}{c}\text { Item 20 (enjoys } \\
\text { movement } \\
\text { activities) }\end{array}$ & $2(7.1 \%)$ & $0(0.0 \%)$ & $2.00(p=.491)$ & \\
\hline
\end{tabular}




\section{Table 5}

Number of Children by Group with Endorsed ADOS-2 Toddler Module Items (ASD-higher MA versus ASD-low MA)

\begin{tabular}{|c|c|c|c|c|}
\hline $\begin{array}{l}\text { ADOS-2 } \\
\text { Toddler } \\
\text { Module Item }\end{array}$ & $\begin{array}{l}\text { ASD-higher } \\
\text { MA Group } \\
n(\%) \\
\text { endorsed } \\
\text { symptom }\end{array}$ & $\begin{array}{c}\text { ASD-low } \\
\text { MA Group } \\
n(\%) \\
\text { endorsed } \\
\text { symptom }\end{array}$ & $\begin{array}{c}\text { Chi-square } \\
\text { (*: significant } \\
\text { after Holm- } \\
\text { Bonferroni } \\
\text { correction) } \\
\text { unadjusted for } \\
\text { sex }\end{array}$ & $\begin{array}{c}\text { AOR } \\
(95 \% \text { CI }) \\
\text { adjusted for sex }\end{array}$ \\
\hline $\begin{array}{l}\text { Al (overall level } \\
\text { of non-echoed } \\
\text { spoken language) }\end{array}$ & $\begin{array}{c}100 \% \\
\text { endorsed }\end{array}$ & $\begin{array}{c}100 \% \\
\text { endorsed }\end{array}$ & N/A & \\
\hline $\begin{array}{l}\text { Ala (frequency of } \\
\text { babbling) }\end{array}$ & $24(100 \%)$ & $26(92.9 \%)$ & $\begin{array}{c}1.78 \\
(p=.493)\end{array}$ & \\
\hline $\begin{array}{l}\text { A2 (frequency of } \\
\text { spontaneous } \\
\text { vocalizations } \\
\text { directed to others) }\end{array}$ & $27(96.4 \%)$ & $28(100 \%)$ & $\begin{array}{c}1.02 \\
(p=1.000)\end{array}$ & \\
\hline $\begin{array}{l}\text { A3 (intonation of } \\
\text { vocalizations and } \\
\text { verbalizations) }\end{array}$ & $11(64.7 \%)$ & $9(52.9 \%)$ & $\begin{array}{c}0.49 \\
(p=.728)\end{array}$ & \\
\hline $\begin{array}{l}\text { A4 (immediate } \\
\text { echolalia) }\end{array}$ & N/A (8's) & N/A (8's) & N/A & \\
\hline $\begin{array}{l}\text { A5 } \\
\text { (stereotyped/idiosy } \\
\text { ncratic use of } \\
\text { words or phrases) }\end{array}$ & N/A (8's) & N/A (8's) & N/A & \\
\hline $\begin{array}{l}\text { A6 (use of } \\
\text { another's body) }\end{array}$ & $19(67.9 \%)$ & $16(69.6 \%)$ & $\begin{array}{c}0.02 \\
(p=1.000) \\
\end{array}$ & \\
\hline A7 (pointing) & $25(89.3 \%)$ & $28(100 \%)$ & $\begin{array}{c}3.17 \\
(p=.236)\end{array}$ & \\
\hline A8 (gestures) & $26(96.3 \%)$ & $26(100 \%)$ & $\begin{array}{c}0.98 \\
(p=1.000) \\
\end{array}$ & \\
\hline $\begin{array}{l}\text { A9 (frequency of } \\
\text { undirected } \\
\text { vocalization) }\end{array}$ & $18(72.0 \%)$ & $22(91.7 \%)$ & $\begin{array}{c}3.16 \\
(p=.138)\end{array}$ & \\
\hline $\begin{array}{l}\text { B1 (unusual eye } \\
\text { contact) }\end{array}$ & $27(96.4 \%)$ & $27(96.4 \%)$ & $\begin{array}{l}\text { NA (cell count } \\
\text { less than 5) }\end{array}$ & \\
\hline $\begin{array}{l}\text { B2 (teasing toy } \\
\text { play) }\end{array}$ & $19(73.1 \%)$ & $19(29.2 \%)$ & $\begin{array}{c}0.25 \\
(p=.745)\end{array}$ & \\
\hline
\end{tabular}




\begin{tabular}{|c|c|c|c|c|}
\hline $\begin{array}{l}\text { ADOS-2 } \\
\text { Toddler } \\
\text { Module Item }\end{array}$ & $\begin{array}{l}\text { ASD-higher } \\
\text { MA Group } \\
n(\%) \\
\text { endorsed } \\
\text { symptom }\end{array}$ & $\begin{array}{c}\text { ASD-low } \\
\text { MA Group } \\
n(\%) \\
\text { endorsed } \\
\text { symptom }\end{array}$ & $\begin{array}{c}\text { Chi-square } \\
\text { (*: significant } \\
\text { after Holm- } \\
\text { Bonferroni } \\
\text { correction) } \\
\text { unadjusted for } \\
\text { sex } \\
\end{array}$ & $\begin{array}{c}\text { AOR } \\
(95 \% \text { CI }) \\
\text { adjusted for sex }\end{array}$ \\
\hline $\begin{array}{l}\text { B3 (unable toy } \\
\text { play) }\end{array}$ & $12(42.9 \%)$ & $23(88.5 \%)$ & $\begin{array}{c}12.30 * \\
(p=.001)\end{array}$ & $\begin{array}{c}9.71 \\
(2.25-41.93)\end{array}$ \\
\hline $\begin{array}{l}\text { B4 (facial } \\
\text { expressions } \\
\text { directed to others) }\end{array}$ & $23(82.1 \%)$ & $28(100 \%)$ & $\begin{array}{c}5.49 \\
(p=.051)\end{array}$ & \\
\hline $\begin{array}{l}\text { B5 (integration of } \\
\text { gaze and other } \\
\text { behaviors) }\end{array}$ & $25(89.3 \%)$ & $28(100 \%)$ & $\begin{array}{c}3.17 \\
(p=.236)\end{array}$ & \\
\hline $\begin{array}{l}\text { B6 (shared } \\
\text { enjoyment) }\end{array}$ & $16(57.1 \%)$ & $19(67.9 \%)$ & $\begin{array}{c}0.69 \\
(p=.582)\end{array}$ & \\
\hline $\begin{array}{l}\text { B7 (response to } \\
\text { name) }\end{array}$ & $19(67.9 \%)$ & $25(89.3 \%)$ & $\begin{array}{c}3.82 \\
(p=.101)\end{array}$ & \\
\hline B8 (ignore) & $26(92.9 \%)$ & $24(88.9 \%)$ & $\begin{array}{c}0.26 \\
(p=.669)\end{array}$ & \\
\hline B9 (requesting) & $26(92.9 \%)$ & $26(92.9 \%)$ & $\begin{array}{l}\text { NA (cell count } \\
\text { less than 5) }\end{array}$ & \\
\hline $\begin{array}{l}\text { B10 (amount of } \\
\text { requesting) }\end{array}$ & $22(81.5 \%)$ & $28(100 \%)$ & $\begin{array}{c}5.70 \\
(p=.023)\end{array}$ & \\
\hline B11 (giving) & $24(85.7 \%)$ & $28(100 \%)$ & $\begin{array}{c}4.31 \\
(p=.111)\end{array}$ & \\
\hline B12 (showing) & $27(96.4 \%)$ & $28(100 \%)$ & $\begin{array}{c}1.02 \\
(p=1.000) \\
\end{array}$ & \\
\hline $\begin{array}{l}\text { B13 (spontaneous } \\
\text { IJA) }\end{array}$ & $16(57.1 \%)$ & $27(96.4 \%)$ & $\begin{array}{c}12.12 * \\
(p=.001)\end{array}$ & $\begin{array}{c}15.21 \\
(1.74-132.82) \\
\end{array}$ \\
\hline $\begin{array}{l}\text { B14 (response to } \\
\text { JA) }\end{array}$ & $12(42.9 \%)$ & $26(96.3 \%)$ & $\begin{array}{c}18.28 * \\
(p<.001)\end{array}$ & $\begin{array}{c}31.68 \\
(3.65-275.40) \\
\end{array}$ \\
\hline $\begin{array}{l}\text { B15 (quality of } \\
\text { social overtures) }\end{array}$ & $28(100 \%)$ & $28(100 \%)$ & NA & \\
\hline $\begin{array}{l}\text { B16a (amount of } \\
\text { social overtures to } \\
\text { examiner) }\end{array}$ & $27(96.4 \%)$ & $29(100 \%)$ & $\begin{array}{l}\text { NA (cell count } \\
\text { less than 5) }\end{array}$ & \\
\hline $\begin{array}{l}\text { B16b (amount of } \\
\text { social overtures to } \\
\text { parent) }\end{array}$ & $25(92.6 \%)$ & $26(92.9 \%)$ & $\begin{array}{l}\text { NA (cell count } \\
\text { less than 5) }\end{array}$ & \\
\hline $\begin{array}{l}\text { B17 (level of } \\
\text { engagement) }\end{array}$ & $26(92.9 \%)$ & $26(96.3 \%)$ & $\begin{array}{l}\text { NA (cell count } \\
\text { less than 5) }\end{array}$ & \\
\hline $\begin{array}{l}\text { B18 (quality of } \\
\text { rapport) }\end{array}$ & $25(89.3 \%)$ & $25(92.6 \%)$ & $\begin{array}{c}\text { NA (cell count } \\
\text { less than 5) }\end{array}$ & \\
\hline
\end{tabular}




\begin{tabular}{|c|c|c|c|c|}
\hline $\begin{array}{l}\text { ADOS-2 } \\
\text { Toddler } \\
\text { Module Item }\end{array}$ & $\begin{array}{c}\text { ASD-higher } \\
\text { MA Group } \\
n(\%) \\
\text { endorsed } \\
\text { symptom }\end{array}$ & $\begin{array}{c}\text { ASD-low } \\
\text { MA Group } \\
n(\%) \\
\text { endorsed } \\
\text { symptom }\end{array}$ & $\begin{array}{l}\text { Chi-square } \\
\text { (*: significant } \\
\text { after Holm- } \\
\text { Bonferroni } \\
\text { correction) } \\
\text { unadjusted for } \\
\text { sex }\end{array}$ & $\begin{array}{c}\text { AOR } \\
(\mathbf{9 5 \%} \mathbf{C I}) \\
\text { adjusted for sex }\end{array}$ \\
\hline $\begin{array}{l}\text { C1 (functional } \\
\text { play with objects) }\end{array}$ & $24(85.7 \%)$ & $28(100 \%)$ & $\begin{array}{c}4.31 \\
(p=.111)\end{array}$ & \\
\hline $\begin{array}{l}C 2 \\
\text { (imagination/creat } \\
\text { ivity) }\end{array}$ & $27(96.4 \%)$ & $28(100 \%)$ & $\begin{array}{l}\text { NA (cell count } \\
\text { less than 5) }\end{array}$ & \\
\hline $\begin{array}{l}\text { C3 (functional and } \\
\text { symbolic } \\
\text { imitation) }\end{array}$ & $23(82.1 \%)$ & $28(100 \%)$ & $\begin{array}{c}5.49 \\
(p=.051)\end{array}$ & \\
\hline $\begin{array}{l}\text { DI (unusual } \\
\text { sensory interests) }\end{array}$ & $15(53.6 \%)$ & $21(75.0 \%)$ & $\begin{array}{c}2.80 \\
(p=.162)\end{array}$ & \\
\hline $\begin{array}{l}\text { D2 (hand/finger } \\
\text { movements) }\end{array}$ & $12(42.9 \%)$ & $15(53.6 \%)$ & $\begin{array}{c}0.64 \\
(p=.593)\end{array}$ & \\
\hline $\begin{array}{l}\text { D3 (other complex } \\
\text { mannerisms) }\end{array}$ & $14(50.0 \%)$ & $21(75.0 \%)$ & $\begin{array}{c}3.73 \\
(p=.097)\end{array}$ & \\
\hline$D 4(S I B)$ & $4(14.3 \%)$ & $3(10.7 \%)$ & $\begin{array}{l}\text { NA (cell count } \\
\text { less than 5) }\end{array}$ & \\
\hline $\begin{array}{l}\text { D5 (repetitive } \\
\text { interests/stereotyp } \\
\text { ed behaviors) }\end{array}$ & $23(82.1 \%)$ & $20(71.4 \%)$ & $\begin{array}{c}0.90 \\
(p=.528)\end{array}$ & \\
\hline E1 (overactivity) & $14(50.0 \%)$ & $21(75.0 \%)$ & $\begin{array}{c}3.73 \\
(p=.097)\end{array}$ & \\
\hline $\begin{array}{l}\text { E2 } \\
\text { (fussiness/irritabili } \\
\text { ty) }\end{array}$ & $16(57.1 \%)$ & $19(67.9 \%)$ & $\begin{array}{c}0.69 \\
(p=.582)\end{array}$ & \\
\hline $\begin{array}{l}\text { E3 (aggression } \\
\text { and disruptive } \\
\text { behavior) }\end{array}$ & $4(14.3 \%)$ & $1(3.6 \%)$ & $\begin{array}{l}\text { NA (cell count } \\
\text { less than 5) }\end{array}$ & \\
\hline E4 (anxiety) & $7(25.0 \%)$ & $6(21.4 \%)$ & $\begin{array}{c}0.10 \\
(p=1.000)\end{array}$ & \\
\hline
\end{tabular}




\section{References}

Adamson, L. B., Bakeman, R., Suma, K., \& Robins, D. L. (2019). An Expanded View of Joint Attention: Skill, Engagement, and Language in Typical Development and Autism. Child Development, 90(1), 1-18. https://doi.org/10.1111/cdev.12973

Akshoomoff, N. (2006). Use of the Mullen Scales of Early Learning for the assessment of young children with Autism Spectrum Disorders. Child Neuropsychology, 12(4-5), 269-277. https://doi.org/10.1080/09297040500473714

American Psychiatric Association. (2013). Diagnostic and statistical manual of mental disorders : DSM-5 (5th ed.). American Psychiatric Publishing. https://search.library.wisc.edu/catalog/9911111397702121

Baio, J., Wiggins, L. D., Christensen, D. L., Braun, K. V. N., Bilder, D., Charles, J., Constantino, J., Daniels, J., Durkin, M. S., Fitzgerald, R. T., Kurzius-Spencer, M., Lee, L.-C., Pettygrove, S., Robinson, C., Schulz, E., Wells, C., Wingate, M., Zahorodny, W., \& Yeargin-Allsopp, M. (2018). Prevalence and Characteristics of Autism Spectrum Disorder Among Children Aged 8 Years - Autism Developmental Disabilities Monitoring Network, 11 Sites, United States, 2012. MMWR Surveillance Summaries, 65(13), 1-23. https://doi.org/10.15585/mmwr.ss6513a1

Barbaro, J., \& Dissanayake, C. (2012). Developmental Profiles of Infants and Toddlers with Autism Spectrum Disorders Identified Prospectively in a Community-Based Setting. Journal of Autism and Developmental Disorders, 42(9), 1939-1948. https://doi.org/10.1007/s10803-012-1441-z

Barton, M. L., Robins, D. L., Jashar, D., Brennan, L., \& Fein, D. (2013). Sensitivity and Specificity of Proposed DSM-5 Criteria for Autism Spectrum Disorder in Toddlers. Journal 
of Autism and Developmental Disorders, 43(5), 1184-1195. https://doi.org/10.1007/s10803013-1817-8

Bishop, S. L., Guthrie, W., Coffing, M., \& Lord, C. (2011). Convergent validity of the Mullen Scales of Early Learning and the Differential Ability Scales in children with autism spectrum disorders. American Journal on Intellectual and Developmental Disabilities, 116(5), 331-343. https://doi.org/10.1352/1944-7558-116.5.331

Charman, T. (2003). Why is joint attention a pivotal skill in autism? Philosophical Transactions of the Royal Society of London. Series B, Biological Sciences, 358(1430), 315-324.

Coulter, K. L., Boorstein, H. C., Barton, M. L., Robins, D. L., Stone, W. L., \& Fein, D. A. (2019). DSM-5 symptom expression in toddlers.

Dawson, G., Toth, K., Abbott, R., Osterling, J., Munson, J., Estes, A., \& Liaw, J. (2004). Early Social Attention Impairments in Autism: Social Orienting, Joint Attention, and Attention to Distress. Developmental Psychology, 40(2), 271-283. https://doi.org/10.1037/00121649.40.2.271

Ellis Weismer, S., Lord, C., \& Esler, A. (2010). Early language patterns of toddlers on the autism spectrum compared to toddlers with developmental delay. Journal of Autism and Developmental Disorders, 40(10), 1259-1273. https://doi.org/10.1007/s10803-010-0983-1

Esler, A. N., Bal, V. H., Guthrie, W., Wetherby, A., Weismer, S. E., \& Lord, C. (2015). The Autism Diagnostic Observation Schedule, Toddler Module: Standardized Severity Scores. Journal of Autism and Developmental Disorders, 45(9), 2704-2720. https://doi.org/10.1007/s10803-015-2432-7

Gardner, L. M., Campbell, J. M., Bush, A. J., \& Murphy, L. (2018). Comparing Behavioral Profiles for Autism Spectrum Disorders and Intellectual Disabilities Using the BASC-2 
Parent Rating Scales-Preschool Form. Journal of Psychoeducational Assessment, 36(6), 535-551. https://doi.org/10.1177/0734282916689438

Guthrie, W., Swineford, L. B., Nottke, C., \& Wetherby, A. M. (2013). Early diagnosis of autism spectrum disorder: stability and change in clinical diagnosis and symptom presentation. Journal of Child Psychology and Psychiatry, 54(5), 582-590. https://doi.org/10.1111/jcpp.12008

Hinnebusch, A. J., Miller, L. E., \& Fein, D. A. (2017). Autism spectrum disorders and low mental age: Diagnostic stability and developmental outcomes in early childhood. Journal of Autism and Developmental Disorders, 47(12), 3967-3982. https://doi.org/10.1007/s10803$017-3278-y$

Johnson, C. P., \& Myers, S. M. (2007). Identification and Evaluation of Children With Autism Spectrum Disorders. Pediatrics, 120(5), 1183-1215. https://doi.org/10.1542/peds.20072361

Kim, So-Hyun, \& Lord, C. (2010). Restricted and repetitive behaviors in toddlers and preschoolers. Autism, 3(4), 162-173. https://doi.org/10.1002/aur.142.Restricted

Kim, S. H., Bal, V. H., Benrey, N., Choi, Y. B., Guthrie, W., Colombi, C., \& Lord, C. (2018). Variability in Autism Symptom Trajectories Using Repeated Observations From 14 to 36 Months of Age. Journal of the American Academy of Child and Adolescent Psychiatry, 57(11), 837-848.e2. https://doi.org/10.1016/j.jaac.2018.05.026

Klin, A., Shultz, S., \& Jones, W. (2015). Social visual engagement in infants and toddlers with autism: Early developmental transitions and a model of pathogenesis. Neuroscience \& Biobehavioral Reviews, 50, 189-203. https://doi.org/10.1016/j.neubiorev.2014.10.006

Lai, M. C., Lombardo, M. V., Auyeung, B., Chakrabarti, B., \& Baron-Cohen, S. (2015). 
Sex/Gender Differences and Autism: Setting the Scene for Future Research. Journal of the American Academy of Child and Adolescent Psychiatry, 54(1), 11-24.

https://doi.org/10.1016/j.jaac.2014.10.003

Lord, C, Risi, S., Lambrecht, L., Cook, E. H., Leventhal, B. L., DiLavore, P. C., Pickles, A., \& Rutter, M. (2000). The autism diagnostic observation schedule-generic: a standard measure of social and communication deficits associated with the spectrum of autism. Journal of Autism and Developmental Disorders, 30(3), 205-223.

http://www.ncbi.nlm.nih.gov/pubmed/11055457

Lord, Catherine, Luyster, R. J., Gotham, K., \& Guthrie, W. (2012). Autism Diagnostic Observation Schedule, Second Edition (ADOS-2) Manual (Part II): Toddler Module. Western Psychological Services.

Luyster, R., Gotham, K., Guthrie, W., Coffing, M., Petrak, R., Pierce, K., Bishop, S., Esler, A., Hus, V., Oti, R., Richler, J., Risi, S., \& Lord, C. (2009). The Autism Diagnostic Observation Schedule_-Toddler Module: A New Module of a Standardized Diagnostic Measure for Autism Spectrum Disorders. Journal of Autism and Developmental Disorders, 39(9), 1305-1320.

Mandell, D. S., Wiggins, L. D., Carpenter, L. A., Daniels, J., DiGuiseppi, C., Durkin, M. S., Giarelli, E., Morrier, M. J., Nicholas, J. S., Pinto-Martin, J. A., Shattuck, P. T., Thomas, K. C., Yeargin-Allsopp, M., \& Kirby, R. S. (2009). Racial/ethnic disparities in the identification of children with autism spectrum disorders. American Journal of Public Health, 99(3), 493-498.

McCrimmon, A., \& Rostad, K. (2014). Test Review: Autism Diagnostic Observation Schedule, Second Edition (ADOS-2) Manual (Part II): Toddler Module. Journal of Psychoeducational 
Assessment, 32(1), 88-92. https://doi.org/10.1177/0734282913490916

Miller, L. E., Burke, J. D., Robins, D. L., \& Fein, D. A. (2019). Diagnosing Autism Spectrum Disorder in Children with Low Mental Age. Journal of Autism and Developmental Disorders, 49(3), 1080-1095. https://doi.org/10.1007/s10803-018-3810-8

Mitchell, S., Cardy, J. O., \& Zwaigenbaum, L. (2011). Differentiating Autism Spectrum Disorder From Other Developmental Delays In The First Two Years Of Life. Developmental Disabilities Research Reviews, 17(2), 130-140. https://doi.org/10.1002/ddrr.1107

Moeschler, J. B., \& Shevell, M. (2014). Comprehensive Evaluation of the Child With Intellectual Disability or Global Developmental Delays. Pediatrics, 134(3), e903-e918. https://doi.org/10.1542/peds.2014-1839

Mullen, E. (1995). Mullen Scales of Early Learning (AGS (ed.)). American Guidance Service Inc.

Mullen, E. M. (1995). Mullen Scales of Early Learning. American Guidance Services.

Mundy, P., Sigman, M., \& Kasari, C. (1994). Joint attention, developmental level, and symptom presentation in autism. Development and Psychopathology, 6(3), 389-401.

Naber, F. B. A., Swinkels, S. H. N., Buitelaar, J. K., Dietz, C., van Daalen, E., BakermansKranenburg, M. J., van IJzendoorn, M. H., \& van Engeland, H. (2007). Joint Attention and Attachment in Toddlers with Autism. Journal of Abnormal Child Psychology, 35(6), 899911. https://doi.org/10.1007/s10802-007-9142-3

Nadig, A. S., Ozonoff, S., Young, G. S., Rozga, A., Sigman, M., \& Rogers, S. J. (2007). A Prospective Study of Response to Name in Infants at Risk for Autism. Archives of Pediatrics \& Adolescent Medicine, 161(4), 378. https://doi.org/10.1001/archpedi.161.4.378 Nevill, R., Hedley, D., Uljarević, M., Sahin, E., Zadek, J., Butter, E., \& Mulick, J. A. (2017). 
Language profiles in young children with autism spectrum disorder: A community sample using multiple assessment instruments. Autism, 23(1), 141-153. https://doi.org/10.1177/1362361317726245

Osterling, J. A., Dawson, G., \& Munson, J. A. (2002). Early recognition of 1-year-old infants with autism spectrum disorder versus mental retardation. Development and Psychopathology, 14(2), 239-251.

Ozonoff, S., Iosif, A.-M., Baguio, F., Cook, I. C., Hill, M. M., Hutman, T., Rogers, S. J., Rozga, A., Sangha, S., Sigman, M., Steinfeld, M. B., \& Young, G. S. (2010). A Prospective Study of the Emergence of Early Behavioral Signs of Autism. Journal of the American Academy of Child \& Adolescent Psychiatry, 49(3), 256-266.e2.

https://doi.org/10.1016/j.jaac.2009.11.009

Ozonoff, S., \& Iosif, A. M. (2019). Changing conceptualizations of regression: What prospective studies reveal about the onset of autism spectrum disorder. Neuroscience and Biobehavioral Reviews, 100(September 2018), 296-304. https://doi.org/10.1016/j.neubiorev.2019.03.012

Ozonoff, S., Macari, S., Young, G. S., Goldring, S., Thompson, M., \& Rogers, S. J. (2008). Atypical object exploration at 12 months of age is associated with autism in a prospective sample. Autism, 12(5), 457-472. https://doi.org/10.1177/1362361308096402

Ozonoff, S., Young, G. S., Landa, R. J., Brian, J., Bryson, S., Charman, T., Chawarska, K., Macari, S. L., Messinger, D., Stone, W. L., Zwaigenbaum, L., \& Iosif, A. (2015). Diagnostic stability in young children at risk for autism spectrum disorder: a baby siblings research consortium study. Journal of Child Psychology and Psychiatry, 56(9), 988-998. https://doi.org/10.1111/jcpp.12421

Paparella, T., Goods, K. S., Freeman, S., \& Kasari, C. (2011). The emergence of nonverbal joint 
attention and requesting skills in young children with autism. Journal of Communication Disorders, 44(6), 569-583. https://doi.org/10.1016/j.jcomdis.2011.08.002

Pierce, K., Gazestani, V. H., Bacon, E., Barnes, C. C., Cha, D., Nalabolu, S., Lopez, L., Moore, A., Pence-Stophaeros, S., \& Courchesne, E. (2019). Evaluation of the Diagnostic Stability of the Early Autism Spectrum Disorder Phenotype in the General Population Starting at 12 Months. JAMA Pediatrics, 173(6), 578. https://doi.org/10.1001/jamapediatrics.2019.0624

Robins, D. L., Casagrande, K., Barton, M., Chen, C.-M. a, Dumont-Mathieu, T., \& Fein, D. (2014). Validation of the Modified Checklist for Autism in Toddlers, Revised With Followup (M-CHAT-R/F). Pediatrics, 133(1), 37-45. https://doi.org/10.1542/peds.2013-1813

Robins, D. L., Fein, D. A., Barton, M. L., \& Green, J. (2001). The modified-checklist for autism in toddlers: An initial study investigating the early detection of autism and pervasive developmental disorders. Journal of Autism and Developmental Disorders, 31(2), 131-144. https://doi.org/10.1023/A:1010738829569

Salley, B., Sheinkopf, S. J., Neal-Beevers, A. R., Tenenbaum, E. J., Miller-Loncar, C. L., Tronick, E., Lagasse, L. L., Shankaran, S., Bada, H., Bauer, C., Whitaker, T., Hammond, J., \& Lester, B. M. (2016). Infants' early visual attention and social engagement as developmental precursors to joint attention. Developmental Psychology, 52(11), 1721-1731. https://doi.org/10.1037/dev0000205

Sparrow, S., Cicchetti, D. V, \& Balla, D. A. (2005). Vineland Adaptive Behavior Scales: Second Edition (Vineland II), Survey Interview Form/Caregiver Rating Form. Pearson Assessments.

Stone, W. L., Lee, E. B., Ashford, L., Brissie, J., Hepburn, S. L., Coonrod, E. E., \& Weiss, B. H. (1999). Can autism be diagnosed accurately in children under 3 years? Journal of Child 
Psychology and Psychiatry and Allied Disciplines, 40(2), 219-226.

https://doi.org/10.1017/S0021963098003370

Thurm, A., Farmer, C., Salzman, E., Lord, C., \& Bishop, S. (2019). State of the Field:

Differentiating Intellectual Disability From Autism Spectrum Disorder. Frontiers in Psychiatry, 10(July), 1-10. https://doi.org/10.3389/fpsyt.2019.00526

Troyb, E., Knoch, K., Herlihy, L., Stevens, M. C., Chen, C. M., Barton, M., Treadwell, K., \& Fein, D. (2016). Restricted and Repetitive Behaviors as Predictors of Outcome in Autism Spectrum Disorders. Journal of Autism and Developmental Disorders, 46(4), 1282-1296. https://doi.org/10.1007/s10803-015-2668-2

Vaughan Van Hecke, A., Mundy, P. C., Acra, C. F., Block, J. J., Delgado, C. E. F., Parlade, M. V., Meyer, J. A., Neal, A. R., \& Pomares, Y. B. (2007). Infant Joint Attention, Temperament, and Social Competence in Preschool Children. Child Development, 78(1), 53-69. https://doi.org/10.1111/j.1467-8624.2007.00985.x

Wolff, J. J., Botteron, K. N., Dager, S. R., Elison, J. T., Estes, A. M., Gu, H., Hazlett, H. C., Pandey, J., Paterson, S. J., Schultz, R. T., Zwaigenbaum, L., \& Piven, J. (2014). Longitudinal patterns of repetitive behavior in toddlers with autism. Journal of Child Psychology and Psychiatry and Allied Disciplines, 55(8), 945-953. https://doi.org/10.1111/jcpp.12207

Woolfenden, S., Sarkozy, V., Ridley, G., \& Williams, K. (2012). A systematic review of the diagnostic stability of Autism Spectrum Disorder. Research in Autism Spectrum Disorders, 6(1), 345-354. https://doi.org/10.1016/j.rasd.2011.06.008

Zwaigenbaum, L., Bauman, M. L., Fein, D., Pierce, K., Buie, T., Davis, P. A., Newschaffer, C., Robins, D. L., Wetherby, A., Choueiri, R., Kasari, C., Stone, W. L., Yirmiya, N., Estes, A., 
Hansen, R. L., McPartland, J. C., Natowicz, M. R., Carter, A., Granpeesheh, D., ... Wagner, S. (2015). Early Screening of Autism Spectrum Disorder: Recommendations for Practice and Research. Pediatrics, 136(Supplement), S41-S59. https://doi.org/10.1542/peds.2014$3667 d$

Zwaigenbaum, Lonnie, Bryson, S. E., Brian, J., Smith, I. M., Roberts, W., Szatmari, P., Roncadin, C., Garon, N., \& Vaillancourt, T. (2016). Stability of diagnostic assessment for autism spectrum disorder between 18 and 36 months in a high-risk cohort. Autism Research, 9(7), 790-800. https://doi.org/10.1002/aur.1585 